\title{
국제사회의 인권에 기반을 둔 개발(RBA) 논의와 한국에의 시사점
}

김 경 아 (KOICA ODA연구실 직원) · 강 공 내 (KOICA 감사실 직원)

목 차
I. 서론
II. 본론
제1장 문헌연구
제2장 사례연구
제3장 정책제언
III. 결론

\section{I . 서론}

인권에 대한 논의는 17 8세기 영국의 권리장전, 미국 독립선언, 프랑스 인권선언 때부터 이 어져 온 오래된 주제로서, 여러 학자들의 다양한 찬반의견이 대두되었으나 아직까지 확정된 정의가 없는 역동적인 주제이다. 인권이란 단순히 인간이라는 이유만으로 부여받는 '자연권’이 라는 주장에 대해 비평가들은 '견고한 이성적 - 이론적 토대가 없는' 애매하고 무른 주장이라고 비판했다. 그러다가 근대에 들어와 1948년 세계인권선언이 선포된 이후 인권의 의미와 범위에 대해 어느 정도 국제적인 합의를 이끌어 내게 되었는데, 여기서 중요한 점은 인권이란 '이미 확정된 형태가 있는 존재'가 아닌 '무엇을 해야 하는가(what should be done)'라는 조건에 대 한 개념이라는 것이다. 즉, 인권선언을 통해 실현되어야 하는 윤리적 주장이 무엇인지가 핵심 이며, 이러한 윤리적 주장을 통해 특정 자유에 대한 중요성을 인식하고, 이 자유를 지키기 위 
해 취해야 할 사회적 의무를 수행하는 과정을 모두 포괄하는 의미이다(Sen, 2009).

인권에 기반을 둔 개발의 개념도 이러한 논리를 바탕으로 한다. 즉, 개발이란 인간의 자유 를 수호하기 위한 수단1)이며, 따라서 인권에 기반을 둔 개발은 '인간의 자유를 지키기 위해 국 제사회가 개발이라는 방법을 이용하여 사회적 의무를 다하는 것'이다.

세계화 시대에 경제적·문화적 대외 교류 부분에서 한국의 국제사회에 대한 영향력이 강해짐 에 따라, 한국의 국제사회의 책임 있는 일원으로서의 역할에 대한 요구가 증가하고 있다. 특히 한국이 2011년 선진 공여국 클럽인 $\mathrm{OECD}$ 개발원조위원회(DAC)에 가입함에 따라, 개발협력분 야에서의 국제사회의 약속과 공여국으로서의 책임을 지킬 의무가 강조되고 있다. 이것이 한국 의 국제적인 인권과 개발 관련 담론의 흐름을 인식하고 그에 따른 의무를 수행해야 하는 이유 이다.

본 연구는 먼저 국제사회의 인권에 관한 주요 조약 및 담론을 소개하면서, RBA가 등장하게 된 배경에 대해 알아보고 개발 분야 중 인권적 시각에서 접근해야하는 주요 분야에 대해 설명하 겠다. 그리고 개발주체별 선진 원조기관들의 $\mathrm{RBA}$ 적용사례를 살펴보고, 우리나라의 법적·제도 적 현황 및 정책 환경을 짚어보면서 향후 우리가 나아가야할 방향에 대해 제언하고자 한다.

\section{II. 본론}

\section{제1장 문헌연구}

\section{1. 인권에 기반을 둔 개발(RBA)의 개념 정의와 접근방법: 왜 인권인가?}

지난 1948년 세계인권선언(the Universal Declaration of Human Rights)이 발표된 이후 ‘인권’이란 개념은 오늘날 국제이슈 전반에 영향을 미치는 주요 화두 중 하나이다. 세계화가 가속화 된 지난 20 여 년간 국제개발 분야에서도 인권에 기반을 둔 개발 담론이 본격적으로 대 두되었다(Gauri \& Gloppen, 2012). 이를 뒷받침 하는 주요 문서로는 세계인권선언과 UN헌장

1) Sen A. (2000) Development as Freedom. Oxford University Press: Oxford. 참고. 
외에도 1966년의 「시민적 및 정치적 권리에 관한 국제규약(the International Covenant on Civil and Political Rights)」과 「경제적·사회적 및 문화적 권리에 관한 국제규약(the International Covenant on Economic, Social and Cultural Rights)」, 1986년의「개발권 선언(the Declaration on the Right to Development)」 및 1993년의 「비엔나 선언(Vienna Declaration and Programme of Action)」 등이 있다. 특히 21세기가 시작되면서 발표된 「새천년 선언(the Millennium Declaration)」2)은 주요 개발과 인권에 관한 원칙을 제시함으 로써 새천년목표(MDGs)3) 등 이후 국제개발 담론의 근간이 되었다(Fukuda-Parr, 2006). 그 리고 이의 효과적이고 범국가적인 시행을 위해 UN인권이사회(the UN Human Rights Council)4)와 UN경제사회문화권리위원회(the UN Committee on Economic, Social and Cultural Rights)가 설치되었다.

세계인권선언에 준거하여 인권이란 '모든 이가 경제, 사회, 문화적, 정치적 권리를 온전히 누릴 때 취할 수 있는 공포와 필요로부터의 자유5)'를 일컫는다(Arzabe, 2001). 1968년 테헤란 에서 개최된 「세계인권회의(World Conference on Human Rights)」는 '인권의 지속적인 이 행의 성공여부는 국가적, 국제적으로 경제사회 발전을 위한 올바르고 효과적인 정책을 수립하 는 데에 달려있다'고 주창했다(Alston \& Robinson, 2005).

반면 '인권에 기반을 둔 개발(Rights-Based Approach to Development, 이하 RBA)'에 대 해 지난 수십 년간 다양한 논의와 시각들이 있었으나 국제적으로 합의된 정의나 지침은 없다. 일례로 세계은행의 Gauri와 Gloppen(2012)은 RBA를 '범세계적, 지역적으로 소외된 자들의 중대하고 결정적인 인권을 지키기 위해 국내외의 자원과 규범을 이용하여 기득권층에 대한 빈 곤층 혹은 그들을 대변하는 자의 요구를 정당화 시키는 원칙(486)'으로 정의한다. 다시 말해 빈곤퇴치를 위한 개발이란 기득권자(선진국의 시민 혹은 개도국의 부유층)의 도덕적인 의무임 과 동시에 빈곤층 스스로 주장해야 할 정치적 권리라는 것이다.

2) 새천년 선언의 주요 내용은 다음과 같다: 세계인권선언을 완전하게 따를 것, 모든 국가가 민주주의와 인권을 도입할 수 있도록 도울 것, '여성에 대한 모든 형태의 차별 금지 협정(CEDAW)'을 도입할 것, 이주 노동자와 그들의 가족의 권리를 보장 및 보호할 것, 모든 국가의 모든 시민들의 참여로써 보다 포괄적인 정치를 위해 다함께 노력할 것, 개발목표 달성에 필수적인 언론의 자유와 정보에 대한 공공의 접근을 보장할 것 (Robinson, 2005).

3) MDGs는 새천년 선언에 비해 인권과 개발권에 대한 논의가 상당부분 축소되었다. 예를 들어 양성평등권의 경우, 경제 및 정치 분야에서의 평등은 제외된 채 교육분야에서의 평등만을 제시하는 한계를 보이고 있다. 그러나 MDGs의 8가지 목표들은 개발의 대표적인 기준을 제시하는 것이 목적이라는 점에서, 개발과 인권의 다양한 이슈들을 전부 다루지 못했 다고 해서 MDGs가 인권과 무관하다고 볼 수는 없다 (Fukuda-Parr, 2006).

4) 1946년 UN인권위원회 (Commission on Human Rights, UNCHR)에서 2006년 UN인권이사회 (Human Rights Council, UNHRC)로 변경.

5) 경제적·사회적 및 문화적 권리에 관한 국제규약(the Covenant on Economic, Social and Cultural Rights) 참고. 
이를 실현시키기 위한 방법으로는 크게 네 가지가 있는데, 먼저 (1) 국가들로 하여금 국제적 규범을 준수 하도록 압력을 가해 인권에 관한 국제조약을 비준하게 하는 것이다. 결과적으로 선진국은 원조를 지속하여 개도국 인권을 향상해야 할 의무를, 개도국 정부는 자국 국민들의 권익과 생활수준 향상을 위한 의무를 지니게 되는 것이다. 그러나 국가권력을 상위하는 국제 조직이 없는 현실에서, 국제조약의 비준이 자동적으로 RBA 실천으로 이어지기는 어려우며 각 국가의 국회를 통한 국내법제화 및 국내 시민사회를 중심으로 한 정치적 동원이 필요하다는 지적이다(Gauri \& Gloppen, 2012). 또한 오늘날 대부분의 국가들은 국제사회의 모범적인 일 원으로서 인권보호를 위한 국제법을 비준하고 있지만, 일부 국가의 경우 이를 국제사회에 보 여주기 용으로만 이용하여 실질적인 국내법 재정과 시행정책으로 이어지지 않거나 혹은 오히 려 이를 방패막이 삼아 국내의 인권유린 상황을 덮는 경우도 있다. 이러한 배경에서 국가별 인 권 조약 준수사항을 감시 감독하기 위해서 Amnesty International이나 Human Rights Watch와 같은 국제 $\mathrm{NGO}$ 의 역할이 점차 중요해지고 있다(Hafner-Burton \& Tsutsui, 2005).

(2) 두 번째는 국제기구 및 공여국의 원조기관을 통한 개발 프로그램을 이용하는 방법이다. 예를 들어 옴부즈맨, 감사 제도 및 보상 제도의 도입 등을 통한 공여기관의 원조 프로그램에 대한 투명성 및 책임 강화 방법이 있다. 또한 원조정책 수립 시 수원국 정부의 인권보호 수준 에 따른 조건부 원조를 실시한다거나, 거시적인 경제성장 보다는 부의 균등한 분배에 집중하 고 소외된 계층을 중심으로 한 원조정책 수립과, 수원국 정부의 주인의식 강화를 위한 빈곤퇴 치전략(PRSP) 수립 등 참여적 개발 정책 등을 수행 할 수 있다(Gauri \& Gloppen, 2012).

(3) 세 번째는 빈곤층의 '권리 의식'을 통한 방법인데, 빈곤층 스스로 자신들의 권리를 인식 하게 하는 것이 먼저라는 주장이다. 국제적인 활동기관과 개도국내의 시민사회간의 공조를 통 한 시너지 효과로 '아래로부터의 정치’가 활발히 진행되어야 한다는 것이다. 그러나 국제적인 시각이 개도국 사회의 전통적인 규범 및 질서와 충돌하게 되는 경우가 많아, 장기적인 관점에 서의 접근이 필요하다(ibid).

(4) 네 번째는 법적 제소를 통하는 방법이다. 즉 정부의 정책수립이 아닌 법원을 통해 소외 된 계층의 권리를 찾아주도록 명령하는 것이다. 일례로 2008년 아르헨티나 대법원은 Matanza-Riachuelo 강 유역의 오염지역을 청소하고 피해자들을 대상으로 한 공청회를 열어 주기적으로 상황을 보고하도록 지방정부에 명령하여 난개발에 의해 피해를 입은 취약계층의 권리를 보호하였다. 이러한 제소를 통한 조치는 정부정책의 시행과 비교했을 때, 취약계층을 타깃으로 한 개별적이고 시급한 문제해결에는 보다 효과적인 것으로 나타났으나 해당 소송의 관련자들에게만 영향을 미치기 때문에, 보다 포괄적인 변화를 위해서는 정부 정책의 시행을 
통한 접근이 보다 효과적이라고 할 수 있다(ibid).

한편 UNDP의 Fukuda-Parr(2006)는 RBA를 '사회적인 적절한 조치를 통해 사람들이 그들 의 권리를 누리고 인간으로서의 존엄성과 자유를 실현시킬 수 있도록 하는 과정(970)'으로 정의 하는데, 여기서의 과정이란 참여, 평등, 투명성, 책임성 및 해결책까지를 일컫는다. 예를 들어 교육 분야 개발에 있어서, 단순히 학교 등록률을 높이는 데에서 그치지 않고 특정 소수 민족의 언어적 장벽 등 까지도 고려한 교육의 평등과 이를 침해받았을 때의 해결책까지도 제시되어야 한다는 것이다. 다시 말해 RBA란 단순히 지원금이나 자선의 도움을 받을 자격이 아닌, 한 사람 의 권리를 보장할 수 있는 사회적인 조치를 받을 자격을 부여하는 것을 의미하는 것이다.

Fukuda-Parr(2006)는 특히 RBA에 있어서 의무를 가진 자의 책임을 강조하고 있다. 개발 에 있어서 의무를 가진 자는 공여국과 수원국의 정부뿐만 아니라 국제사회, 기업, 언론, 시민 사회 전반을 포함한다. 빈곤의 일차적인 책임은 개도국 정부에 있다는 기존의 관념을 거부하 면서, 지금의 세계화 추세에서 빈곤은 더 이상 한 국가의 능력으로는 해결 할 수 없는 문제이 기 때문에 이는 국제사회가 해결해야할 책임이 있다는 주장이다. IMF, 세계은행, WTO로 대 변되는 신자유주의 체제하에서 글로벌 자본은 국내자본에 비해 상대적으로 국내법의 제재를 받지 않는다. 신자유주의를 표방하는 선진국가들은 글로벌 자본의 유치를 위해 국제무역 장벽 을 낮추고, 구조조정 실시 및 공기업 민영화를 추진하였으며 기업 활동에 대한 규제폐지와 복 지서비스의 단계적 폐지를 진행하였다. 역으로 글로벌 기업들 또한 그들에게 유리한 시장을 찾아 자유롭게 이동할 수 있기 때문에, 자신들의 공장이 있는 개도국 정부에게 기업 활동에 불 리한 정책을 시행하지 못하도록 압력을 행사하였다. 이는 결국 개도국 정부의 기본적인 교육, 보건 분야에 대한 사회적 안전망의 붕괴를 야기하였으며, 노조의 약화와 고용의 불안정성을 심화시켰다. 따라서 세계화는 사회경제적인 권리를 시장경제 성장에 따른 결과물의 하나로 전 락하게 만들었으며, 다국적기업의 횡포를 규제할 국가의 권력을 무력화시키고, 세계화에 따른 인구의 대이동은 시민의 인권을 국가가 보호할 수 없는 상황으로 만들었다(Ghai, 2001).

이러한 배경에서, 빈곤과 인권의 문제를 국제사회의 원조로써 해결해야 하는 이유는 크게 세 가지가 있다. 첫째, 개도국들은 재정적·인적 자원이 부족하다. 올바른 정책수립과 자원 동 원 능력을 가졌다고 해도 개도국 정부가 확보할 수 있는 자원은 한계가 있다. 이를 보완하기 위해서는 개발원조, 부채탕감, 민간 투자 등이 필수이다. 둘째, 원자재의 국제 가격 폭락이나 관세 증가 등 국제적인 상황변화에 따른 불안요인으로 인해 개도국 경제는 큰 영향을 받는다. 실제로 '개발권(right to development)'은 지난 1970-80년대 국제 경제 상황 적응을 위해 개 도국 정부들이 제안한 개념이다6). 현재 개도국에게 불리하게 적용되는 많은 무역 정책과 기후 
변화 관련 제약들을 보다 개도국 사정에 맞는 정책으로 변화시킬 필요가 있다는 주장이다. 나 아가 큰 이윤이 남지는 않지만 개도국에 만연한 질병에 대한 치료약 개발과 열악한 환경에서 도 잘 성장하는 곡물의 개발 및 국제적인 인신매매에 대한 근절 조치 등은 국제적인 공조를 통 해 해결해야 될 과제이다. 마지막으로, 국제적인 결정사항에 개도국의 목소리가 충분히 반영 되지 못하는 현실이다. 이는 국제적인 거버넌스의 민주성과 투명성을 약화시킨다. 대표적인 예로 $\mathrm{WTO}$ 의 무역 협상에서 개도국의 의견보다는 힘 있고 부유한 국가의 이익을 더 많이 반영 하게 된다는 것이다(Fukuda-Parr, 2006).

그러나 현실적으로 인권 침해에 대한 요인은 여러 가지이기 때문에, 이에 대한 책임을 특정 누군가에게 지우기는 어렵다. 즉 개발에 대한 인권의 중요성은 누구나 다 인식하고 공감할 수 있지만, 어느 특정 국제기구를 집어서 개발에 대해 책임을 묻기는 불가능하다. 그러나 그렇다 고 해도 국제사회의 의무가 전혀 없다고는 말할 수 없는데, Fukuda-Parr(2006)는 이를 '불완 전 의무(imperfect obligation)'7)라고 칭한다. 한 국가 혹은 지역사회가 해결할 수 없는 문제 를 국제사회가 해결할 수 있다면, 이는 이유여하를 막론하고 국제사회의 의무라는 것이다. 그 러나 이를 법적인 책임으로는 규정할 수 없으며, 국제사회의 관련자들 간의 컨센서스를 이루 어 각 공여국의 위정자들로 하여금 정부의 정책으로 이어질 수 있게 독려해야 한다.

덧붙여 2005년 UNDP의 주도하에 설립된 「빈곤층 법적권한강화 위원회(the Commission on the Legal Empowerment of the Poor, CLEP)」의 시각에 따르면, 빈곤의 근본 원인은 빈곤층이 법으로부터 '배제' 되었기 때문이며 결과적으로 합법적이고 공정하게 사회·경제·정치 적 권한을 누릴 수 있는 기회를 '박탈' 당했기 때문이다. 따라서 빈곤층의 법적 권한 강화는 빈 곤퇴치의 수단임과 동시에 목적이다. 이를 위해서 빈곤층에 대한 법의 접근성, 재산권, 노동 권, 사업권을 강화해야하며, 이는 빈곤층의 착취와 학대를 방지하고 정치적인 장을 마련하여 보다 정당한 사회를 구현하는데 도움이 될 것으로 주장한다(Cousins, 2009).

이렇듯 $\mathrm{RBA}$ 에 관한 각 기구 및 학자 간 시각은 상이하며 다양한 해석이 존재한다. 정리하 자면, 개발의 논의에 인권적 시각을 도입하는 것은 규범적인 의미에서 개발원조의 도덕적인 면을 부각시키고, 실용적인 의미에서는 국가뿐만 아니라 국제사회 전반에 책임과 의무를 강조 하여 국제개발협력을 더욱 촉진한다는 점에 의미가 있다. 또한 기존의 반정치적인 개발 담론8)

6) Sengupta A. (2000) The Right to Development. UN ESCOR Commission on Hum. 참고.

7) Sen A. (2009) The Idea of Justice. Harvard University Press: Cambridge, MA. 참고.

8) Ferguson J. (1994) Anti-Politics Machine: Development, Depoliticization, and Bureaucratic Power in Lesotho. University of Minnesota Press 참고. 
을 다시 '정치화'하여 개발의 주체인 빈곤층의 민주적이고 자발적인 참여를 이끌어 낸다는 데 에 의의가 있다(Cornwall \& Nyamu-Musembi, 2004).

\section{2. 인권에 기반을 둔 개발(RBA)의 범위와 적용방안: 인권이 개발에 미친 영향은?}

제2차 세계대전 이후 본격적으로 대두된 개발분야와 인권분야는 서로의 상호연관성을 인식 하고 있었으나 효과적인 협력방안을 쉽게 찾지 못해 각자의 영역에서 활동해 왔다. 경제학자, 사회학자, 정책입안자들을 중심으로 이루어진 개발분야와 정치활동가, 변호사 및 철학자 등으 로 구성된 인권분야는 개념적인 차원에서는 서로의 교집합을 찾을 수 있었으나, 실제적으로 인권조약과 법률을 빈곤퇴치를 위한 구체적인 개발정책 및 프로그램에 접목시키는 것은 또 다 른 차원의 문제였기 때문이다. 그러다 1997년 Kofi Annan 전 UN사무총장이 모든 UN기구에 인권을 주류화(mainstreaming)하도록 지시하면서 본격적으로 '인권에 기반한 원조(RBA)'라 는 개념이 도입되기 시작했다(Alston \& Robinson, 2005; Robinson, 2005).

인권과 개발을 접목시키는 방법은 다시 말해 인권에 대한 국제적인 규범에 입각하여 개발의 계획, 정책 및 과정을 재해석하여 반영하는 것을 의미한다. 인권의 키워드는 크게 (1) 포함 (inclusion)과 무차별(non-discrimination), (2) 국가 및 지역의 주인의식(ownership), (3) 책임성 (accountability)과 투명성(transparency), (4) 참여(participation)와 권한강화(empowerment) 로 정리할 수 있는데(Robinson, 2005), 이를 RBA에 적용시키면〈표 1〉과 같다.

\section{〈표 1〉 RBA의 주요 적용 방안}

\begin{tabular}{|c|c|}
\hline 인권 & RBA \\
\hline - 포함과 무차별 & $\begin{array}{l}\text { - 보다 완전하고 이성적인 개발 프레임워크 } \\
\text { - 개발정책의 의도치 않은 피해 보상을 위한 포괄적 안전망 설치 } \\
\text { - 개발정책에 대한 보다 효과적이고 완전한 분석 }\end{array}$ \\
\hline - 주인의식 & - 개도국 시민의 주인의식 제고 \\
\hline - 책임성과 투명성 & $\begin{array}{l}\text { - 공여국과 수원국 정부 등 개발수행자의 책임성 제고 } \\
\text { - 개발정책의 규범적 투명성과 구체성 제고 } \\
\text { - 개발과정의 투명성 제고와 컨센서스 확보의 용이성 제고 }\end{array}$ \\
\hline - 참여와 권한강화 & $\begin{array}{l}\text { - 개도국 시민의 권한강화 } \\
\text { - 개도국 시민의 자유롭고, 유의미하며 적극적인 참여 활성화 } \\
\text { - 애드보커시 권위(authority)의 제고 }\end{array}$ \\
\hline
\end{tabular}

(출처: Robinson, 2005를 참고로 저자 작성) 
정리하자면, 인권의 개념이 개발에 도입됨으로써 인간으로 살아가면서 당연히 누려야 할 기 본 권리를 박탈당한 소외계층에 보다 집중을 할 수 있으며, 나아가 단순한 수치상의 성장이 아 닌 인간 개개인의 존엄성까지 개발의 범주에 넣는 계기가 되었다고 할 수 있다. 따라서 「UN 세계인권선언 제 25 조에서 강조한 분야9)인 식량과 건강, 취약층(여성과 아동)을 중심으로 $\mathrm{RBA}$ 가 도입된 것은 지극히 자연스러운 결과일 것이다. 이 절에서는 먼저 주요 인권 분야와 그 에 대한 개발이슈를 짚어보고자 한다.

\section{가. 식량권}

식량에 대한 권리를 단순하게 '배고픔으로부터의 자유'로 정의하기 쉽지만, 현실적으로 식량 권은 복잡한 양상을 띤다. 예를 들어, 식량권을 ‘하루에 두 끼를 먹을 수 있는 권리’, ‘하루에 특정 칼로리를 섭취할 수 있는 권리’, ‘영양결핍과 관련된 질병에 걸리지 않을 권리’ 등으로 다 양하게 해석할 수 있다. 그러나 ‘적정 영양의 섭취’라고 해도 이는 깨끗한 물, 건강, 위생 등 식량 외적인 요인들도 같이 작용하기 때문에 식량권만으로는 이루기 어렵고, '충분한 음식의 섭취’라고 해도 필수 영양소의 함유여부까지는 보장하기 어렵다(Drèze, 2005). 한편 Gaiha(2003)는 식량권을 '(생존에 필요한) 최소한의 음식에 대한 권리'라고 정의하고, 국가와 공여자는 기아와 영양결핍을 없애는 것에 초점을 맞춰야 한다고 주장한다.

같은 맥락으로, 식량권에 대한 정확한 책임 소재를 가리는 것 또한 어렵다. 예를 들어 남아 선호사상이 팽배한 사회의 한 가정 내에서 부모가 아들을 먹이기 위해 딸을 굶게 할 경우, 이 는 부모만의 책임으로 볼 수 있을까? Drèze(2005)는 이러한 경우 일차적인 책임은 국가에 있 다고 주장하는데, 국가는 국내의 모든 자원에 대한 명령권을 가지며, 헌법에서 명시한 기본권 을 수호할 책임이 있기 때문이다. 이렇듯 직접적인 책임이 아닐 경우에도 국가는 국민의 식량 권에 대한 최소한의 보장을 해야 하는 데, 그 방법은 모든 초등학교의 의무적 점심식사 제공을 명령한 2001년 인도 라자스탄 주(州) 대법원 판결에서 찾아볼 수 있을 것이다.

1966년 수립되고 1976년 발효된 「경제적·사회적 및 문화적 권리에 관한 국제규약(the International Covenant on Economic, Social and Cultural Rights, 이하 ICESCR)」은 '충 분하고 적절한 식량에 대한 권리(Right to Adequate Food, 이하 RtAF)'의 개념을 처음으로

9) 'Everyone has the right to a standard of living adequate for the health and well-being of himself and of his family, including food, clothing, housing and medical care and necessary social services, and the right to security in the event of unemployment, sickness, disability, widowhood, old age or other lack of livelihood in circumstances beyond his control.' (1948 UN세계인권선언 제25조) 
국제사회에 제시하였으며 이후 1978년 UN세계식량회의가 개최되어 「기아와 영양결핍 퇴치 를 위한 세계선언(the Universal Declaration on the Eradication of Hunger and Malnutritio n)」으로 결실을 맺었다. 특히 ICESCR의 제 11조는 RtAF에 대한 대표적인 문서로서, 정부가 취해야할 구체적인 정책과 방안을 제시하고 있다. ICESCR 제 11조에 대한 실천적 방안을 도 출한 1999년의 ICESCR 위원회의 'General Comment 12'에서는 RtAF의 정의로서 '하루에 필 요한 최소한의 칼로리, 단백질 및 미량영양소를 섭취할 권리 뿐만 아니라, 나아가 이를 위해 필요한 식량에 접근할 물리적이고 경제적인 권리'까지 다루고 있다(Gaiha, 2003; Beuchelt \& Virchow, 2012).

그렇다면 관건은 '식량 접근권'의 실현이다. 세계화에 의해 글로벌 곡물시장이 요동치고 한 국가의 식량안보의 문제가 대두되는 지금의 상황에선, 앞서 예로 든 인도 라자스탄의 경우는 지극히 지역적이고 단편적인 해결방안이라고 할 수 있다. 식량에 대한 접근이 한 국가의 능력 범주를 넘어선다는 사실은 바이오연료의 예에서 찾아볼 수 있다. 다국적기업의 바이오연료 플 랜테이션은 해당 국가의 전통적인 토지사용을 왜곡시킬 뿐만 아니라, 농업용수 등 농업기반 자원 및 시설에 대해 영향을 끼친다. 특히 브라질 정부와 미국의 바이오연료 기업간 맺은 계약 으로 인해 국내 옥수수 가격이 폭등하여 브라질 시민의 식량에 대한 접근권이 현저하게 침해 된 사례는, 정부의 식량권에 대한 의무와 나아가 $\mathrm{WTO}$ 의 국제무역에 따른 인권침해 방지 의무 를 저버린 대표적인 사례라고 할 수 있다(Haugen, 2012). 이에 Narula(2005)은 세계화 시대 에 다국적기업과 국제재정기구(International Financial Institutions, IFIs)가 인권에 대한 국제적 규범의 사각지대에 놓여있기 때문에, 현재의 국제법을 재정비하여 이러한 기업과 기구 에게 인권보호에 대한 책임과 의무를 지울 필요가 있다고 주장한다.

\section{나. 건강권}

$\mathrm{WHO}$ 헌장에 따르면, 건강이란 '단순한 질병의 퇴치뿐만 아니라 완전한 육체, 정신, 사회적 안녕'까지 아우르는 포괄적인 의미이다. 건강권에 관련한 기본 문서는 세계인권선언과 ICESCR을 비롯하여 1946년의 「WHO Constitution」 과 1978년의 「알마아타 선언 (Declaration of Alma-Ata)」이 있다(Meier, 2010). ICESCR의 제 12조에서는 건강권을 '가 능한 최고의 육체적 및 정신적 건강을 누릴 수 있는 권리10)'로 정의하면서, 이를 위해 국가들 로 하여금 다음과 같은 조치를 취할 것을 권고했다.

10) 'The States Parties to the present Covenant recognize the right of everyone to the enjoyment of the highest attainable standard of physical and mental health.' (ICESCR 제 12조) 
(1) 사산율과 영유아 사망률의 감소 및 아동의 건강한 성장을 위한 법률제정

(2) 다각적인 환경 및 산업 위생의 향상

(3) 전염병, 풍토병, 직업병 및 기타 질병에 대한 예방, 치료 및 관리

(4) 발병시 모든 의학 서비스 및 치료를 보장할 조건의 마련

위의 권고안은 모두 법률 제정과 그에 따른 정책을 통해서만 실현될 수 있기 때문에, Eberl et al. (2011)은 주권을 가진 국가들이 건강권을 수호할 첫 번째 책임이 있다고 주장한다. 국가 의 책임은 크게 세 가지 면으로 구분될 수 있는데, (1) (국민들의) 건강권을 누릴 자유를 직·간 접적으로 침해하지 않는 것, (2) 위의 권고안을 수행하는데 제 3자의 개입을 막는 방안을 마련 하는 것, 그리고 (3) 건강권의 완전한 실현에 필요한 적절한 법적, 행정적, 예산적, 사법적인 조치를 취하는 것이다.

그러나 위에서 언급한 국가의 의무는 기본적으로 해당 국가의 국적을 가진 자를 대상으로 하기 때문에 무국적자들, 특히 세계화에 따라 급격히 증가한 불법이주노동자들과 국제분쟁에 따른 난민들은 이러한 보호 장치의 사각지대에 놓이게 되었다. 이러한 무국적자들이 기본 국 가의료서비스에서 배제됨으로써 전염병과 같이 전체 공공보건에 약영향을 미칠 수 있는 요인 들이 적절하게 관리되지 못한다는 현실적인 이유도 있지만, 1985년 「 $\mathrm{UN}$ 이주민에 대한 인권 선언11)」에 따라 기본적인 건강권은 인권의 시각에서 국적자, 무국적자를 구분하지 않고 적용 되어야 한다(Romero-Ortuño, 2004).

또한 최근의 신자유적인 시각에서는 건강관리 및 의료 서비스가 국가의 몫이 아닌 시장에서 교환 될 수 있는 상품의 하나로 취급되면서 여러 문제들이 발생하고 있다. 즉, 상품의 시장가 격을 지불할 수 없는 빈곤계층이 기본적인 의료 서비스의 혜택을 받지 못하게 되는 것이다. 나 아가, WTO의 「지적재산권에 대한 다자간 규범(Trade Related Intellectual Properties, 이 하 TRIPS)」은 개도국에서 만연한 질병에 대한 의약품의 생산단가를 높이는 결과를 가져왔 다. 일례로 개도국에 특히 심각한 피해를 주고 있는 AIDS에 대한 치료약 개발의 경우, TRIPS 의 특허권 보호로 인해 치료약을 개발한 선진국의 제약회사에 천문학적인 라이센스 요금을 지

11) 'Nothing in this Declaration shall be interpreted as legitimizing the illegal entry into and presence in a State of any alien, nor shall any provision be interpreted as restricting the right of any State to promulgate laws and regulations concerning the entry of aliens and the terms of and conditions of their stay or to establish differences between nationals and aliens. However, such laws and regulations shall not be incompatible with international legal obligations of the State, including those in the field of human rights.' (1985 UN Declaration on the Human Rights of Individuals Who are not Nationals of the Country in which They Live. Article 2.1) 
불해야 하기 때문에, 개도국의 제약회사는 자체적으로 치료약을 개발 및 생산할 엄두를 내지 못하고 있다. AIDS 외의 여타 개도국 풍토병 등을 위한 치료약 또한 시장이 작고, R\&D 비용 대비 수익성이 낮다는 이유로 다국적 제약회사들이 생산을 꺼려하고 있는 실정이다. 이에 1999년 OXFAM과 같은 국제NGO들은 시애틀 WTO장관급 회의에 맞춰 「암스테르담 선언」 을 발표, 소외된 질병에 대한 국제사회(선진공여국 및 다국적 제약회사)의 책임공유 및 치료약 에 대한 접근권 강화를 주장하였다(Hoen, 2003).

\section{다. 아동권리와 교육권}

아동권리는 1924년의 「제네바 아동권리선언(Geneva Declaration of the Rights of the Child)」, 1959년 UN총회의「아동권리선언」, 1948년의「세계인권선언」, 1966년의「시 민적 및 정치적 권리에 관한 국제규약(the International Covenant on Civil and Political Rights)」의 제 23조 및 24조와 ICESCR의 제 10조에 명시되어 있다. 특히 1989년의 「UN 아동권리협약 (UN Convention on the Rights of the Child)」에 의하면, 아동은 단체결사의 자유(제 15조), 초등교육을 받을 권리(제 28조), 휴식과 오락을 취할 권리 (제 31조), 위해한 노동을 하지 않을 권리 (제 32조), 성착취 및 인신매매로부터 보호받을 권리 (제 34조, 35조) 를 갖는다.

아동권리 중 특히 노동(child labor)과 교육은 아동 복지에 가장 밀접한 관련이 있기 때문 에, 두 이슈를 동시에 다룰 필요가 있다. 2008년 UNICEF의 통계조사에 따르면, 35 개 개도국 중 7 세부터 14 세 사이의 아동 인구의 $25 \%$ 가 노동활동을 하고 있었으며, 아동노동의 비율이 높 을수록 학교 출석률이 낮았고 따라서 빈곤 확률도 높아지는 것으로 나타났다. 특히 부모의 교 육수준이 낮을수록 자녀를 학교에 보내지 않고 노동을 시킬 확률이 높았는데, 이는 교육이 아 동에게만이 아닌 세대 전반에 중요한 영향을 미친다는 것을 확인할 수 있다.

아동노동에 관한 대표적인 국제적 논의는 1989년 UN아동권리협약 외에도 ILO의 「 1973 년 최소 연령에 대한 컨벤션(the Minimum Age Convention)」과 「1999년 최악의 아동노동 형 태에 관한 컨벤션(the Worst Forms of Child Labor Convention)」이 있다. 1973년 컨벤션 에서 국제사회는 노동할 수 있는 최소연령을 만 15 세로 정하였으나, 개도국의 경우 아동의 정 신적·신체적 위해를 가하지 않고 학교 수업에 지장을 주지 않는 '가벼운 노동'의 경우에 한정 하여 13 15세 혹은 12 14세부터 일할 수 있다고 합의하였다. 두 번째 1999년 컨벤션에서는 이보다 진보하여 무상 초등교육의 의무적 실시와 직업교육을 포함한 중등교육의 설치를 촉구 
하였다. 이 두 컨벤션을 통해 현실적으로 아동노동이 다른 이슈와 연계된 복잡한 문제라는 점 과, 국가 및 문화별로 차별화된 접근방법이 필요하다는 것을 국제사회가 인식하는 계기가 되 었다(Betcherman et al., 2005).

2002년 ILO의「Every Child Counts: New Global Estimates on Child Labour」 보고서 에 따르면, 아동의 성별에 따른 노동 현황에서 '위해한 노동(hazardous labor)'에 남아가 여아 보다 더 많이 종사하고 있었으며(55:45의 비율), 가장 극단적인 사례로 소년병(child soldiers) 의 경우를 들 수 있다. 전 세계 30 여개 분쟁국에서 18 세 미만 소년병들의 수는 30 만 명이 넘 으며, 이 중 12 만 명이 사하라이남 아프리카 국가들에 있다. 이들 소년병들의 나이는 최소 7 8세에서 15 18세까지 다양하며, 이들이 입은 정신적·신체적인 피해는 매우 심각하다. 특히 이들이 전쟁을 끝내고 일상으로 돌아온다고 해도, 가족이 사망하고 집과 학교가 파괴되는 등 주변 환경의 급격한 변화 때문에 일상으로의 적응이 어려운 경우가 많아, 다각적인 보호조치 가 필요하다(ibid).

한편, 교육에 있어서 여아들이 남아들보다 교육의 기회를 박탈당하는 경우가 많았는데, 이 는 특히 서남아, 동남아 지역과 사하라이남 아프리카 지역에서 특히 두드러졌다. 교육에서의 성차별에 대해 언급한 대표적인 사례는 MDGs의 목표 3 '양성평등 및 여성지위 향상'의 '2005 년까지 초등교육 및 중등교육에서, 2015년까지 모든 교육에서 성별 격차 제거'에서 찾아볼 수 있다. 학교에 등록하지 않거나, 등록을 해도 결석률이 높거나, 혹은 중도 포기하는 주된 원인 은 교육보다는 노동을 선호하는 상황 때문이다. 이러한 상황은 특히 부모들에 의해 강요되는 경우가 많은데, 부모들의 이러한 결정의 원인은 자녀를 교육함으로써 얻을 수 있는 이득에 대 해 제대로 인식하지 못하거나, 자녀를 학교에 보낼 경제적 여건이 되지 않기 때문이다. 이를 해결하기 위해 Betcherman et al. (2005)은 아래〈표 2)와 같은 방안을 제안한다.

ILO는 아동노동을 줄이고 교육을 활성화하기 위한 방안으로 Time-Bound Program (TBP) 를 제안했는데, 이는 개도국 정부로 하여금 정해진 시간 안에 구체적인 목표와 세부적인 시행 방안을 가지고 국가발전계획과 국내 노동정책(아동노동 포함) 및 교육정책을 연계하여 국가 빈곤퇴치에 기여토록 하는 것이다. 현재 엘살바도르, 네팔, 탄자니아를 시작으로 도미니카 공 화국, 코스타리카, 필리핀 등이 시행하고 있다(ibid). 


\section{〈표 2〉아동노동과 관련한 교육 진흥 방안}

\begin{tabular}{c|l}
\hline & - 보다 쉬운 등교 (학교 수의 증가, 수업시간의 유연한 운영) \\
교육에 대한 & - 수업료의 감액 혹은 무료화 \\
장점의 강종에 대한 차별 철폐 & - 교육 수준의 제고 (교육기술 및 교재 등) \\
& - 기본시설의 향상 (깨긋한 식수 제공 등) \\
& - 아동 노동에 대한 임금 차별의 철폐 (아동노동에 대한 수요 감소) \\
\hline & - 빈곤퇴치전략 \\
교육에 대한 & - 사회 안전망 \\
장애물부 직접현금지급(cash transfer) 및 식량지급 (교육 및 보건 & 서비스에 대한 참여와 연계) \\
& - 신용 및 담보물 이용에 대한 접근권 강화 \\
\hline 교육장려 및 & - 노동시장 기능의 향상 \\
아동노동 금지 & - 의무 교육법의 시행 \\
관련 법적 조치 & - 적절한 아동노동법의 도입 및 시행 \\
실시 & - 임금차별금지 법안 등의 시행 \\
\hline 노동 아동에 & - 위해하고 최악의 형태의 노동으로부터 아동의 격리 \\
대한 보호 및 & - 건강 및 안전 등 고용기준의 시행 \\
갱생 서비스의 & - 교육 및 건강 서비스의 제공 \\
제공 & - 직업교육 및 기타 갱생 서비스의 제공
\end{tabular}

(출처: Betcherman et al., 2005 p.188을 참고로 저자 번역)

현실적으로, 개도국 정부가 위와 같은 정책을 시행하는 데에는 여러 어려움이 따른다. 기본 적으로 개도국은 근로감독관 수가 부족하고, 이들 마저도 수도에 상주하여 대부분의 아동 노 동이 이루어지는 지방과는 지리적 거리가 멀며, 또한 이들 아동의 대다수가 가내 수공업이나 미등록 사업장에서 일을 하기 때문이다. 덧붙여 명심해야 할 것은, 아동과 노동에 관련한 문제 는 매우 민감한 사안이기 때문에 정부 혹은 국제사회의 개입 자체가 의도치 않은 부작용을 일 으킬 수 있다는 점이다. 2001년 UNICEF 보고서12)에 의하면, 아동노동에 대해 선진국의 정부 및 소비자 단체가 반대 운동을 벌이자, 무역 상대국을 잃을 것을 걱정한 방글라데시의 의류공 장들이 5 만 명이 넘는 아동 노동자들을 해고하여 결국 더 위험하고 낮은 임금의 일자리로 이 직하게 만든 경우도 있다(ibid). 국제사회 및 국가들이 개발정책을 계획 및 시행할 때, 다른 개 발 분야 보다 더 신중하게 아동권에 대한 접근이 이루어져야 하는 이유이다.

12) UNICEF, 'Poverty and Children: Lessons of the 90s for Least Developed Countries', Policy Review Document, Division of Evaluation, Policy, and Planning (New York: UNICEF, 2001) 참고. 


\section{라. 여성권리}

여성권리에 대한 개념은 먼저 UN헌장과 세계인권선언에서 '인종, 성별, 언어 및 종교에 대 한 차별을 금지'한 것에서 찾을 수 있다. 1946년에는 UN경제사회이사회(ECOSOC)가 여성권 리 전담 특별기구인 「UN 여성지위위원회(the Commission on the Status of Women)」를 설치하였는데, 초기에는 UN 인권위원회의 소위원회로서 설치되었으나, 같은 해 UN인권위원 회와 동등한 독립 위원회로서의 지위13)를 획득하였다. 당시 UN인권위원회 의장 등이 '여성'이 라는 특정 그룹을 대상으로 한 별도 위원회 설치에 대해 반대 의견을 표했으나, 이에 대해 당 시 UN여성지위위원회 의장이었던 Begtrup은 '여성의 문제는 인류역사상 처음으로 국제적인 관심과 진지한 연구의 대상이 되었으며 따라서 여성지위위원회를 소위원회를 하는 것은 이러 한 특수성을 왜곡시킬 것이다'라고 주장하였다. 이는 여성의 문제를 '모든 사람(all human beings)의 권리’라는 통합적인 틀에서 보지 않고14), 여성이 처한 사회·경제·정치·문화적인 (공 적영역 및 사적영역 전반의) 특수상황을 인정하기 시작한 분수령이 되었다(Leeuwen, 2009).

모든 사람이 아닌 여성에 초점을 맞춘 문서로는 1979년의 「여성에 대한 모든 형태의 차별 철폐에 관한 국제협약(the Convention on the Elimination of All Forms of Discrimination against Women, $\mathrm{CEDAW})$ 이 대표적이며, 여성권리의 기틀을 다지게 된 주요 회의로는 먼 저 1993년 비엔나 세계인권회의가 있다. 당시 회의장 안팎에서는 '여성의 권리가 인권이다 (Women's rights are human rights)'는 슬로건을 내세운 여성단체의 운동이 활발하게 진행 되었으며(Leeuwen, 2009), 그 성과로 같은 해 UN총회에서 「UN 여성에 대한 폭력 철폐 선 언(UN Declaration on the Elimination of Violence against Women)」이 채택되었다 (Hassmann, 2011).

특히 1995년의 베이징 세계여성회의는 1975년부터 시행된 세계여성회의의 네 번째 회의로, 여기서 채택된 「베이징 선언(Beijing Declaration)」과 이를 위한 '행동강령(Platform for Action)'은 여성의 사회·경제·정치적 권한강화를 위한 구체적인 목표와 행동계획을 제시하였 다. 베이징 회의는 기존의 터부시 되었던 주제들 (전통문화와 종교적 믿음에 반하는 가족의 구 성, 성적 자기결정권, 전쟁시의 강간 등 성범죄, 여성 지도자, 낙태 등)을 국제적인 논의의 장

13) UN Division for the Advancement of Women (DAW), Short History of the Commission on the Status of Women, http://www.un.org/womenwatch/daw/CSW60YRS/CSWbriefhistory.pdf, accessed on 2013.1.15. 참고.

14) 일부 학자들은 기존의 'Human Rights'에서의 ‘Human'이란 사실상 '남성'을 지칭하며, 따라서 서양, 백인, 부르주아지, 자유주의, 자본주의 및 가부장제도 중심의 시각을 내포한다고 주장한다 (Hassmann, 2011). 
으로 이끌어 내어 대부분의 UN회원국으로부터 양성평등에 대한 지지를 얻었다는 데에 큰 의 의가 있다. 또한 행동강령에서는 '여성, 여성의 권리 및 여자아이의 발전을 위한 주요 관심사 항’으로 빈곤, 교육 및 훈련, 건강, 폭력, 평화, 경제구조 및 정책, 결정권을 제시하였으며, 각 국 정부로 하여금 동 행동강령을 시행하기 위한 구체적인 개발전략 및 행동계획을 1995 년까지 수립하도록 하였다(Roberts, 1996).

여성이 인권 담론의 주요 논제가 되면서, 자연스럽게 여성의 사회·경제·정치적 개발에 대한 논의도 활발히 이루어졌다. 여성은 특히 개도국의 사회개발분야(육아, 교육, 보건, 복지, 지역 사회 발전 등)에 핵심적 역할을 하는 것으로 나타나, 여성의 권한강화와 국가개발이 밀접한 상 호연관성이 있다고 할 수 있다. 예를 들어 정치적·경제적·사회적으로 자주적인 여성은 그렇지 않은 여성 및 일반 남성들에 비해 그들이 가진 자원을 자신이 아닌 자녀, 가족, 지역사회의 발 전을 위해 사용하는 것으로 조사되었다. 또한 어머니의 교육수준이 높을수록 자녀의 취학률이 높았으며, 영아사망률 또한 낮게 나타났다(Hassmann, 2011).

1970년대 초반, 미국의 자유주의 페미니스트들을 중심으로 여성의 활발한 경제활동 참여를 옹호하는 'Women in Development (WID)' 용어가 사용되기 시작했다. WID는 1950년대 70 년대 주류를 이루었던 근대화와 산업화를 배경으로 경제적 생산분야에서의 평등주의 및 성차 별 철폐를 주장하였으며, 여성들도 남성과 같이 생산분야에 참여 할 수만 있다면 성평등을 이 룰 수 있다는 시각이 주를 이루었다. 그러나 WID의 접근법으로는 여성노동이 남성노동의 부 수적인 차원으로 취급당하면서 새로운 기술에 대한 교육의 기회는 남성에게만 국한되어 결과 적으로 여성은 핵심 노동에서 벗어난, 저임금의 단순노동에만 머무르게 되었다. 이에 대한 비 판으로 1970년대 후반에 등장한 'Women and Development (WAD)'는 신마르크스주의적 접 근을 기반으로, 여성은 근대화 이전부터 사회·경제발전에 기여 해 왔기 때문에 단순히 경제활 동 참여여부가 문제가 아니라 구조적인 문제, 즉 제 3 세계 여성의 빈곤은 세계 정치·경제 구조 에서 북에대한 남의 종속적 관계에 기인한다고 주장하였다. 그러나 WAD도 사적영역에서의 여성의 재생산활동(가사, 출산, 육아 및 노약자와 병자 돌봄 등) 보다는 공적영역에서의 경제 중심적 생산활동만을 다루었으며, 여성을 사회계급 및 인종에 따른 차별화된 접근이 아닌 하 나의 동일한 그룹으로 보았다는 점에 한계가 있다. 이후 1980년대 등장한 'Gender and Development (GAD)'는 사회주의적 관점에서 공적 및 사적영역 모두에서 여성의 생산 및 재 생산활동 전반을 다루었으며, 가부장사회에서 고착화 된 남성성과 여성성의 정치사회적 역학 관계와 성역할, 즉 '젠더’ 관계를 재조명하였다. GAD의 접근법은 개발정책 수립 시 정치·사회. 문화적 계급에 따른 여성들의 다양한 목소리를 반영할 수 있게 하였으며, 나아가 여성의 법적 
권리 강화와 토지소유권·재산권과 같은 경제적 권리 강화에 기여하였다(Rathgeber, 1990).

19세기 후반 수십 년간의 여성운동의 결실로 2000년 MDGs 목표3 '양성평등 및 여성지위 향상'이 세워졌고, 동일한 목적으로 2010년에는 UN여성기구(UN Women)가 설립되었다. 이 는 UN개혁의 일환으로 기존의 UN산하 여성관련 부서(DAW, INSTRAW, OSAGI, UNIFE $\left.\mathrm{M}^{15)}\right)$ 를 통합한 것으로써, UN여성지위위원회 등 국제적 기구의 정책·세계기준·규범 수립을 지 원하며, UN회원국들이 이러한 기준을 도입하기 위한 기술적·재정적 지원 제공 및 시민사회와 의 파트너십을 구축하고, 정기적인 모니터링을 통하여 양성평등을 위한 UN시스템의 책임성을 제고하는 것을 주요 역할로 하고 있다(UN Women, 2010).

이러한 국제사회의 노력에도 불구하고, 여전히 세계 많은 곳에서 양성평등이 이루어지지 못 하고 있다. 앞서 언급한 「 $\mathrm{UN}$ 여성차별철폐협약」의 비준 문제만 봐도, 미국의 경우 국내 보 수주의자들의 강력한 반대에 부딪혀 아직 비준되지 못하고 있는 실정이다. 특히 동 협약의 제 5 조 a항 '남성과 여성의 우월적 및 열등적 지위 혹은 정형화된 성역할에 기반한 편견과 관습의 철폐'의 경우 여성의 어머니·아내·돌보는자로서의 신성한 역할에 대한 역사적·종교적 신념을 무너트려 사회의 근간을 흔들 것이라는 주장이 강하다. 이렇듯 양성평등의 담론은 기본적으로 기존의 정치·사회·문화적 틀을 뒤엎는 정치적인 접근이기 때문에, 국제조약의 비준과 국내법 제정 및 정책 수립에 대한 각국 정부의 부담이 가장 크다고 할 수 있다(Ramdas \& Janus, 2011).

\section{3. 소결}

제 1장을 정리하자면, 인권은 지난 반세기 동안 국제적인 규범으로서 정착되어 왔으며, 국 제사회의 모든 국가들은 인권을 수호할 의무를 가진다. 그러나 이것은 단순히 국제조약 비준 으로 해결되지 않으며, 정부의 구체적인 정책 수립과 강력한 시행 의지가 필요하다. 그러나 다 국적기업 등의 인권침해 등 세계화에 의해 국경과 국적이 모호해 짐에 따라 국가보호의 사각 지대에 놓인 인구가 증가하고 있다. 때문에 UN을 중심으로 한 범국가적이고 강력한 규제조치 및 인권보호 방안이 마련되어야 한다. 인권은 전 인류적 개념으로서, 한 국가의 자주권을 상위 하기 때문이다. 이러한 맥락에서, 범국가적인 인권 보호 및 증진을 위해서 공여국은 수원국의

15) Division for the Advancement of Women (DAW), International Research and Training Institute for the Advancement of Women (INSTRAW), Office of the Special Adviser on Gender Issues and Advancement of Women (OSAGI), UN Development Fund for Women (UNIFEM). 
인권에 기반을 둔 개발정책을 수행할 의무가 있다. 이는 개도국의 인권 보호를 위한 법률적 장 치 마련뿐만 아니라, 식량권 및 건강권과 같은 기본권과 여성 및 아동 등 사회 취약층에 대한 인권보호를 목적으로 다각적인 개발 프로그램을 수행하는 것을 의미한다. 그럼 다음 장에서는 각 개발협력 주체별 $\mathrm{RBA}$ 담론의 실제 적용 사례를 살펴보겠다.

\section{제2장 사례연구}

\section{1. 개발협력 주체별 사례연구}

앞서 살펴본 바와 같이, 인권에 기반을 둔 개발(RBA)을 수행하는데 있어서 개발협력 주체 들의 의지와 노력이 가장 핵심요소라고 할 수 있다. 이번 장에서는 먼저 다자기구, 양자기구 및 민간부문을 중심으로 선진원조의 사례를 살펴보고, 우리나라의 현실을 짚어보고자 한다.

\section{가. 다자기구 : 국제금융기구를 중심으로16)}

\section{(1) 거버넌스와 법치주의}

제2차 세계대전 종전 직후 작성된 세계은행 설립을 위한 협정조항(the Articles of Agreement) 은 오직 경제적 판단기준만을 제시하고 있다. 그러나 지난 60 년의 세월동안 국제개발 환경과 그에 따른 주요 담론이 변함에 따라, 세계은행 또한 빈곤퇴치를 위해서는 경제성장과 사회적 형평성을 동시에 이루어야 한다고 인식하기 시작했다. 대표적으로 개도국의 '투자환경’을 올바 르게 하기위해 '굿 거버넌스(good governance)' 개념을 도입하였는데, 국가신용도를 높이기 위해서는 정치사회적 안정과 행정의 투명성이 우선되어야 한다는 것이다.

세계은행은 특히 사법에의 접근, 법 앞의 평등, 사법부의 독립 및 올바른 공공분문 관리 등 ‘법치주의’를 강조하였다. 1970 년대 중반 세계은행이 실시한 사업의 $58 \%$ 를 인프라부문이 차지 했던 것과는 달리, 2000 년대 중반에는 인프라부문은 $22 \%$ 로 감소한 반면 인간개발 및 법제 개 혁 부문은 $52 \%$ 로 증가한 것이 단적인 예다. 오늘날 세계은행은 광범위한 '법적-사법적 개혁' 이니셔티브로써, 약 600 여개의 금융지원사업과 16 개의 단일 프로젝트(free-standing proj-

16) 개발과 인권관련 주요 국제기구로는 UN기구를 중심으로 세계은행, IMF 및 OECD DAC의 GOVNET이 있다. 그러나 UN기구에 대한 논의는 앞 장에서 다루었기 때문에 생략하며, GOVNET 또한 정책 컨설팅 및 전문가 정보공유가 중심 인 협의체 수준이기 때문에 제외한다. 
ects)를 진행하고 있다. 일례로 볼리비아의 사법개혁 프로젝트의 경우, 사법부의 사법시스템 개혁을 지원하여 사법에의 접근, 사법 서비스의 효율성 및 시민사회의 참여를 제고하고 있다. 이를 통해 민간부문의 활동을 촉진함으로써 경제 성장에 기여하는 한편, 모든 시민들의 기본 권리를 보장함으로써 사회 복지를 향상시키는 것을 목표로 한다(Dañino, 2005).

그러나 $\operatorname{Horta}(2002)$ 는 세계은행의 이러한 거버넌스에 대한 강조는 화려한 수사에 지나지 않는다고 비판한다. 실제 세계은행은 주요 고객을 잃지 않으려고 권위주의적 정부를 지원하는 자가당착적 모습이 숨겨져 있다는 것이다. 예를 들어 인도네시아 Suharto 정권과 자이르의 Mobutu 정권의 인권탄압·억압 정책에도 불구하고 세계은행의 재정지원은 계속 되었다. 특히 인도네시아의 경우 동티모르에 대한 불법 점령과 그에 따른 인권탄압이 자행되는 와중에도 세 계은행의 지원은 계속되었으며 그 중 $1 / 3$ 이상이 정권실세의 개인 주머니로 들어갔다는 사실 이 이를 극명하게 보여준다. 그 밖의 민주콩고, 르완다, 우간다의 지속적인 분쟁에 따른 인권 유린에도 불구하고 세계은행은 해당국들의 지하자원 수출에 따른 국가경제성장을 높게 평가하 며 금융지원을 계속하고 있는 실정이다. Amnesty International의 보고에 따르면, 1990년대 후반 건설된 차드-카메룬간 송유관 건설로 인해 수많은 노동자들의 생명이 위협받았으며, 특 히 해당 지역의 원주민들(카메룬 Bakola지역의 Pygmy 주민들)의 삶의 터전을 파괴하는 등 기 본적인 인권보호 장치가 제대로 작동하지 못하고 있다.

이에 Horta(2002)는 세계은행을 비롯한 공여국들이 재정지원이나 원조사업을 수행함에 있 어서 수원국 정부의 거버넌스 문제만을 다루지 말고 수원국 시민이 처한 정치적 상황과 시민 권도 함께 고려해야 한다고 조언한다. 덧붙여 원조실적을 평가할 때 얼마나 많은 재정적 지원 이 이루어졌는지, 즉 돈이 얼마나 투입되었는지를 집계하기보다 실제 수혜자의 삶의 질의 얼 마나 향상되었는지를 척도로 해야 한다고 주장한다. 세계은행의 사례는 수원국의 인권 문제가 공여기관의 정치적인 판단과 무관하지 않으며, 공여국의 의지가 중요성을 보여주는 단적인 예 라고 할 수 있겠다.

\section{(2) 빈곤퇴치전략과 참여적 개발}

2000년대 초반, UN인권고등판무관실(the Office of the High Commissioner for Human Rights, OHCHR)은 빈곤퇴치전략(Poverty Reduction Strategies, 이하 PRS)에 인권을 반영 하는 것을 골조로 하는 가이드라인을 제시하여 추상적 논의에 머물렀던 $\mathrm{RBA}$ 를 실제 개발정책 에 적용 가능한 수준으로 정착시키고자 하였다. IMF와 세계은행이 MDGs 달성 방안의 일환으 
로 제시한 PRS는 저소득국이 참여적 개발을 통한 빈곤퇴치전략 정책수립 및 집행방안을 마련 하는데 일조할 것을 목적으로 한다. 즉 각 국가 정부로 하여금 인권정책의 우선순위를 정하여 구체적이고 실현가능한 전략과 지표를 설정하고, 그 과정에서 현장과 이해관계자들의 다양한 목소리가 반영될 수 있도록 빈곤층의 직접참여를 독려하는 공개 간담회 등을 실시하도록 하는 것이다. 핵심은 이렇게 설정된 인권 정책은 별도의 정책이 아닌 빈곤퇴치라는 공동의 목표 하 에서 PRS에 통합되어 구현된다는 것이다(Plant, 2005).

그러나 PRS는 형식적인 방법론일 뿐이며, 수원국 정부의 정책수립 과정을 더욱 복잡하게 만들고 선택의 범위를 제한시키는 등17) 행정 부담을 가중시킨다는 비판적 시각도 있다. 의견 수렴과정만 해도, 민주적 절차를 거치지 않은 각 지역사회의 대표자들이 구성원의 모든 목소 리를 대변할 수 있는가에 대한 문제가 제기될 수 있으며, 특정 이슈에 관해 그룹별 의견이 첨 예하게 대립할 경우, 정부의 판단은 정치적이 될 수밖에 없다. 이에 대해 $\mathrm{IMF}$ 와 세계은행은, 참여적 절차 그 자체로써 참여자들의 인권 강화가 될 수 있으며, 다만 공청회 계획 시 참가자 들의 관심사와 지식정도를 세심하게 고려하고 공청회 방식 또한 정책수립을 위한 기술적인 논 의가 아닌 지역사회활동을 중심으로 이루어져야 한다고 주장한다. 또한 공여국이 일방적으로 수립해 준 정책은 현지 사정을 제대로 반영하지 못하여 실패할 확률이 높은 반면, PRS는 수원 국 정부 스스로 사전에 제약조건에 대한 대책을 수립할 수 있게 하여 정책 시행의 실패를 줄이 는 효과를 가진다(ibid).

거버넌스, $\mathrm{PRS}$ 등 인권에 기반한 '조건부 원조'의 특징은 수원국 정부에 추가적인 부담을 지우게 되는 것이 사실이다. 그러나 인권 담론은 기본적으로 정치적이며 다른 요소들과 복잡 하게 얽혀있기 때문에, 단기간에 해결할 수 없다. 따라서 조건을 이행하지 못했다는 이유로 수 원국에 대한 원조를 일시에 철회한다면 더 큰 피해를 야기할 수 있기 때문에, 조건의 기준을 가장 핵심적인 사안에 대한 최소한의 기준을 설정하여 수원국 정부가 수원자격이 될 수 있도 록 하는 현실적인 접근도 필요할 것이다(Uvin, 2004).

\section{나. 양자기관 : 스위스 SDC, 영국 DfID, 스웨덴 Sida를 중심으로}

공여국 정부들은 국제 인권 체제하에서, 개발협력의 방향을 인권의 기준과 원칙에 따라 정 할 필요성을 인식하게 되었다. 이에 양자원조기관들은 다양한 인권 적용방안들을 모색하였는 데, 주요 형태를 정리하자면 〈표 3〉과 같다(Piron, 2005).

17) 브레튼우즈 기관의 신자유주의적 정책 도입을 강요한다는 주장도 있다 (Uvin, 2004). 


\section{〈표 3〉 개발협력에 인권적용 방안}

\begin{tabular}{|c|c|}
\hline (1) 정책협의 & $\begin{array}{l}\text { 상대국 정부(외교부)와의 공조를 통한 최적의 인권의무 충족방안 } \\
\text { 협의 }\end{array}$ \\
\hline (2) 역량강화 & 정부와 시민사회의 인권보호 역량 강화 프로그램 구성 \\
\hline (3) 기금조성 & $\begin{array}{l}\text { 국제적, 지역적, 국가적 수준의 인권기금 조성 } \\
\text { (예: Canada Funds, DfID Good Governance Funds, AusAid } \\
\text { Fund) }\end{array}$ \\
\hline (4) UN지원 & $\begin{array}{l}\text { RBA관련 UN시스템에 대한 지원 } \\
\text { (예: UN 산하기구 회의에 대한 재정지원) }\end{array}$ \\
\hline (5) NGO지원 & 국제 및 지역 인권 $\mathrm{NGO}$ 와의 협업 \\
\hline $\begin{array}{l}\text { (6) 모니터링 및 } \\
\text { 평가 }\end{array}$ & $\begin{array}{l}\text { 인권관련 원조정책의 영향력 모니터링 및 평가를 통한 원조의 부정 } \\
\text { 적 영향('피해를 주지 말라(Do No Harm)' 원칙)에 대한 인식제고 }\end{array}$ \\
\hline (7) 원조의 중지 & $\begin{array}{l}\text { 극단적 상황(예: 미얀마 민주화 운동 이후의 인권탄압) 발생 시 원조 } \\
\text { 의 일시 중지 혹은 UN 인도적지원 사업 등에 제한된 원조의 실시 }\end{array}$ \\
\hline (8) 정책일관성 & 국제기구 및 타 정부부처와의 정책일관성 수립 \\
\hline
\end{tabular}

(출처: Piron, 2005를 참고로 저자 작성)

인권을 위한 원조정책은 그 자체의 특수한 실시 목적과 방법이 필요하지만, 동시에 '범분야 (cross-cutting theme)'로서 다른 정책 및 프로그램과의 상호연관성도 고려해야 한다. 일례로 1993년 스위스 정부는 인권, 민주주의 및 법치주의를 외교정책의 최우선 과제로 선정하였으 며, 이에 1997년 스위스 외교부와 개발협력기관(Swiss Agency for Development and Cooperation, 이하 SDC)은 인권 가이드라인을 수립하였다. 그러나 가이드라인만으로는 SDC 의 사업수행 방식의 변화를 이끌어내는데 한계가 있었다. 개발협력과 인권에 대한 다양한 해 석이 혼재하였고, 대부분 정치적 권한강화나 거버넌스 향상을 위한 프로젝트에 치중하였다. 수원국의 인권 수준에 따른 '조건부 원조' 또한 지속적으로 적용되지 못하였다. 이를 해결하기 위해 SDC는 조직개편을 통해 거버넌스 부서에 인권 관련 모든 업무를 집중함과 동시에, SDC 의 근본가치인 빈곤퇴치와 인권간의 연계성에 집중하여 사회적 권리와 경제적 권리가 동등하 게 지켜져야 함을 강조하였다. 다른 공여국과의 협의, 직원 교육, 국가프로그램에 대한 조언을 통해 전반적인 $\mathrm{SDC}$ 의 원조 전달 방식이 인권에 기반을 두도록 노력하고 있다(ibid).

원조기관에게 $\mathrm{RBA}$ 를 도입한다는 의미는, 단순히 몇 가지 인권관련 신규사업을 추가하거나 문서상의 가이드라인을 수립하는 차원이 아닌, 조직 전체의 근본적인 변화를 의미한다. 즉 개 발협력의 개념 및 목표를 재정립하고 그에 따른 전략을 재수립해야하는 것이다. 때문에 호주 
의 AusAID는 RBA에 대한 공통된 개념이 정립되지 않았고, RBA에 대한 강조가 자칫 원조 전 반에 제약을 줄 수 있다는 염려 때문에 2001년 RBA를 도입하지 않기로 결정하였으며18), 다른 여러 공여국들(캐나다 등)은 여전히 RBA 도입여부를 검토 중에 있다. 반면 영국, 노르웨이 스 웨덴과 같은 북유럽 공여국들은 $\mathrm{RBA}$ 를 적극적으로 도입하였는데, 영국의 국제개발부 (Department for International Development, 이하 DfID)는 RBA 도입에 따른 이점과 필요 성을 다음과 같이 주장하였다(ibid: emphasis in original).

(1) $\mathrm{RBA}$ 는 국제적 컨센서스를 바탕으로 명백한 국제기준을 수립하고 개인의 권리와 국가의 의무를 명확하게 함으로써 개발원조의 규범적 틀을 제공한다. 공여국은 이러한 기준을 이용하여 현재체제에 대한 도전을 지원할 수 있으며 (정책변화에 대한 시민사회의 로비 활동 지원 등), 정부기관의 업무수행을 향상시킬 수 있고 (공정한 재판 등), 비정부기관 의 활동을 규제하거나 (노동기준 제시) 국가 자원의 배분 (사회보호 등)을 가이드 할 수 있다.

(2) 인간을 더 이상 단순한 개발프로젝트의 수혜자가 아닌 권한과 권리를 가진 적극적인 시 민으로서 개발 과정의 중심에 놓을 수 있다. 결과적으로 빈곤층에 대한 정부의 책임을 강조하고 시민들이 자신의 권리를 주장하고 정책결정에 참여할 수 있는 권한을 강화시킴 으로써, 원조는 국가-사회간 관계변화에 기여할 수 있으며 이는 '사회계약'의 강화로 이 어진다.

(3) 취약층 및 소외계층에 대한 차별에 보다 집중할 수 있다. 공여국은 개발의 혜택으로부터 구조적으로 소외당한 특정 집단이 포함된 통계자료를 수집 할 수 있게 되어, 보다 효과 적인 빈곤퇴치 정책 수립을 지원할 수 있다.

(4) 국회, 사법기관 및 지역사회 등 개발사업 참여자들의 책임을 강화시킬 수 있다.

(5) 원조의 부작용에 대한 경각심 제고와 공여국-수원국 간 열린 대화를 통한 파트너십 강 화를 통해 원조의 계획 및 전달 방식을 향상시킬 수 있다.

영국은 1997 년 새로운 노동당 정부가 들어서면서, 윤리적인 외교정책 수립의 일환으로 개도 국의 빈곤퇴치와 사회·경제적 권리강화를 최우선 과제로 내세웠으며, 1997년과 2000년 DfID 백서에 인권이 명시되었다. 특히 2000년 DfID의 목표전략문서(Target Strategy Paper)에서 는 '참여(participation), 포함(inclusion), 의무이행(fulfilling obligations)'의 세 가지 원칙

18) AusAid (2001) Putting Things to Rights: The Use of Foreign Aid to Advance Human Rights in Developing Nations, submission to the Human Rights Sub-Committee of the Joint Standing Committee on Foreign Affairs, Defence and Trade on its Inquiry into the Link Between Aid and Human Rights, February. 참고. 
을 중심으로 $\mathrm{DfID}$ 의 새로운 RBA 시행방안이 작성되었다. RBA의 초점을 '거버넌스' 분야에 맞 춘 여타 북유럽 국가와는 달리, $\mathrm{DfID}$ 는 빈곤층의 ‘참여적 접근을 통한 권한강화’를 중요시 하 였다. 이를 위해 UN기구에 대한 자금지원, 새로운 참여적 권한(participatory rights) 평가방 법의 개발, 참여와 포함을 중심으로 한 국가개발(남미 중심) 프로그램의 구성, 시민사회에 대 한 지원, $\mathrm{PRS}$ 관련 사회분야(학교 관리 등)에서의 참여적 접근의 촉진 등 다양한 사업을 진행 하였다(ibid).

스웨덴의 국제개발협력기관(Swedish International Cooperation Agency, 이하 Sida) 또한 가장 선도적인 RBA 수행 기관으로 평가된다. 스웨덴 정부는 1970 년대부터 개발협력과 인권을 연계해왔으나, 1997-8년에 공식적으로 모든 외교정책 전반에 인권을 적용하기로 발표하였다. Sida의 기본 원조 목표 또한 '빈곤층 삶의 향상 및 민주적 개발'로써, 인권 그 자체가 개발협력 의 목적임과 동시에 RBA가 개발협력의 효과성을 제고한다고 보고 있다. Sida의 이러한 인권 중심적 시각은 국제 인권 규범에 기반을 두고 있어, 협력국과 동일한 가치 및 규범을 제공하고 있다. Sida는 정책대화, 인권 프로그램의 개발, 다른 섹터에서의 인권 주류화를 통해 RBA를 시행하고 있으며, 전체 개발사업의 $1 / 4$ 정도를 인권 및 민주주의 사업이 차지하고 있다. 이를 위해 국가개발전략 수립을 위한 국가 분석 시 병행하는 '민주주의 및 인권 평가'를 위한 안내 지침 제작 등 상당한 예산을 직원의 역량강화 훈련에 투자하고 있다. 이러한 노력은 지역 및 섹터별 (예를 들어 동유럽, 보건분야 등) 인권정책 수립에 기여하고 있다19).

Sida의 RBA 성공요인은 스웨덴의 일반대중 및 정치권 전반을 아우르는 인권 중시 문화에서 찾을 수 있다. 특히 스웨덴은 국내 및 국외 정책들 간 일관성이 강한데, '국가 인권 행동강령 (National Human Rights Action Plan)'을 통해 인권이 ODA 정책 전반에 적용되도록 하였으 며, 2004년에는 「Shared Responsibility: Sweden's policy for global development」 법 률20)을 제정하여 인권과 빈곤퇴치를 중심으로 한 평등하고 지속가능한 개발을 주창하였다 (ibid).

정리하자면, 각국의 원조기관들은 $\mathrm{RBA}$ 도입을 결정하기 전에 우선 다음 사항을 검토할 필

19) Sida (2003) Country Strategy Development: Guide for Country Analysis from a Democratic Governance and Human Rights Perspective, Stockholm; Sida (2001) A Democracy and Human Rights-Based Approach in Swedish Development Cooperation, Stockholm; Sida (1997) Justice and Peace: Sida"s Programme for Peace, Democracy and Human Rights, Stockholm. 참고.

20) Swedish Government (2003) Shared responsibility: Sweden"s policy for global development. Government Bill 2002/03, Stockholm. 참고. 
요가 있다(Piron, 2005). (1) 기관의 전반적인 목표가 (빈곤퇴치뿐만이 아닌) RBA 중심으로 수 정될 수 있는가? (2) 인권과 관련된 국제적 규범 및 국내법이 원조기관에 어떠한 영향을 미치 는가? (3) RBA가 원조기관의 모든 직원의 업무 전반에 적용되어야 하는가, 아니면 권고사항일 뿐인가? (4) $\mathrm{RBA}$ 를 위한 조직역량개발에 얼마나 투자 할 수 있는가? (직원 교육 등) (5) RBA를 위한 원조사업 예산을 얼마나 확보할 수 있는가? (신규 인권개발프로젝트 수행 혹은 예산지원 (budget support) 등) (6) 기관의 규범과 업무수행 방식을 변화시킬 수 있는가? (7) RBA에 입 각하여 모니터링 및 평가를 할 수 있는가?

Piron(2005)은 또한, RBA가 단순한 수사에 그치지 않고 실제 원조사업에 적용되기 위해서 는 다음과 같은 조건이 충족되어야 한다고 조언한다. (1) 국내외 호의적인 환경의 조성, (2) 관 련부처 장관 및 기관의 임원 등 고위급 인사의 (변화에 대한) 약속 및 헌신, (3) 정책강령에 대 한 정확한 전달 및 실제 프로그램에의 적용을 위한 수단(tool)의 제공, (4) 자원의 프로젝트로 의 전환(transferring resources into projects), (5) RBA를 내면화하기 위한 업무 시스템 및 방식의 수정, (6) 직원이 $\mathrm{RBA}$ 를 이해하고 적용할 수 있는 역량의 개발.

이와 같이 $\mathrm{RBA}$ 는 공여기관의 근본적인 변화와 강한 의지를 필요로 하기 때문에, 공여국마 다 각자의 원조 목적과 상황에 따라 차등 적용하고 있다. 실제로 북유럽 국가들을 제외한 대부 분의 공여국들은 순수 인권보호를 위한 원조보다는 자국의 이해관계에 따라 원조를 제공하고 있다. Barratt(2008)의 연구결과에 따르면, 비구속성 원조의 경우 RBA를 적용하는 경우가 있 지만, 구속성 원조의 대부분은 공여국의 무역관계 증진 목적에 따라 원조여부를 결정하는 것 으로 밝혀졌다. 즉, 공여국의 해외시장 개척 및 잠재적 무역 파트너로서의 가치가 인정된다면 수원국의 인권 수준이 아무리 열악하다 할지라도 큰 문제가 되지 않는 것이다.

\section{다. 민간부문 : 국제 $\mathrm{NGO}$ 를 중심으로}

국제 $\mathrm{NGO}$ 는 다양한 분야에서 국제기구 및 국가들의 활동에 대한 견제 및 옹호활동을 펼쳐 왔으며, 개발분야에서는 특히 시민·정치적 권리 및 기본권 수호를 위한 활동을 집중적으로 펼 쳐왔다. $\mathrm{RBA}$ 를 적극 지지하는 국제 $\mathrm{NGO}$ 의 입장 및 지향점은 여러 인권관련 국제회의에서 발 표된 성명서에서 찾을 수 있는데, 대표적으로 2000년 호주 인권위원회(Human Rights Council of Australia), CARE International 및 스웨덴 Save the Children의 성명서를 들 수 있다. 또한 2001년 Amnesty International의 최고결정기구는 경제·사회·문화적 권리 개발프 로그램을 시행하기 위한 연구방법의 개발, 정책 우선순위 선정, 지지 활동 등을 포함하는 새로 
운 미션을 도입하였으며, 2002년 Food First는 미국 정부의 ICESC 비준을 촉구하는 캠페인 을 벌였다. 이처럼 국제 $\mathrm{NGO}$ 는 국제 개발원조 기관들(다자 및 양자기관)로 하여금 인권 수호 의 의무를 다하도록 압력을 가하는 수단으로써의 역할을 수행하고 있다(Nelson \& Dorsey, 2003).

국제 $\mathrm{NGO}$ 들은 보다 효과적으로 정부기구 혹은 국제 신자유주의 경제체제에 대항하기 위해 다른 $\mathrm{NGO}$ 들 및 국제기구와 협력관계를 구축하고, 국제 노동·환경·여성 등 다양한 이슈에 대 한 정책결정에 강한 목소리를 반영해 왔다. $\mathrm{NGO}$ 간 공조를 통한 국제적 캠페인의 대표적 사례 로는 지구환경보호 및 온난화 방지 캠페인, 소년병 제도의 철폐 캠페인 등을 들 수 있다. 또한 대규모 국제 $\mathrm{NGO}$ 는 지역사회의 소규모 $\mathrm{NGO}$ 의 활동을 지원하기도 하는데, 예를 들어 여성의 생식 및 성적 권리 등 여성건강과 관련된 개발프로그램을 시행하고 있는 International Women's Health Coalition이 나이지리아의 Girl's Power Initiative를 지원하여 해당 지역의 소녀들과 여성들의 성적 권리 교육을 실시한 경우를 들 수 있다(ibid).

세계화에 따른 다국적기업의 영향력이 커짐에 따라, 기업의 사회적 책임(corporate social responsibility)에 대한 $\mathrm{NGO}$ 의 캠페인도 활발해 졌다. 일례로 'Clean Diamonds' 캠페인은 캐 나다와 영국 정부 및 World Vision과 Amnesty International이 공조하여 시에라리온과 라이 베리아의 다이아몬드 수출에 따른 수익에 대한 군부지도자의 접근을 제한한 캠페인이다. Exxon-Mobil, GAP, Nike 등 대표적인 다국적 기업의 환경 및 노동권(특히 아동과 여성노동) 에 대한 영향을 견제하기 위해 「국제 알권리 캠페인(International Right to Know Campaign)」 등 다양한 국제 NGO의 캠페인도 진행되었다. 또한 원주민의 토지소유권 및 문 화권, HIV/AIDS 감염자의 의약품에 대한 권리, 소년병 사용 철폐를 위한 캠페인(the Coalition to Stop the Use of Child Soldiers) 등 특정 이슈 및 소외계층을 타깃으로 한 캠페 인도 대표적인 사례이다(ibid).

국제 $\mathrm{NGO}$ 들도 물론 스스로의 개발 프로젝트에 $\mathrm{RBA}$ 를 도입하기 위해 사업수행방식의 변경 에서부터 직원의 인권전문성 교육까지 다양한 노력을 기울이고 있다. CARE는 기관 전체의 $\mathrm{RBA}$ 에 대한 이해제고, 주인의식 및 적용의 심화를 강조하였고, OXFAM은 직원들의 변화를 쉽게 하기 위한 개념적 프레임워크를 개발하였으며, 스웨덴 Save the Children은 RBA가 아 이들에게 어떠한 영향을 미치는지 확인하길 원하는 회원·공여자·후원자들이 쉽게 이해할 수 있는 접근법을 개발하였다(ibid). 
최근 RBA에 있어서 $\mathrm{NGO}$ 를 비롯한 시민사회의 역할이 점차 강조되고 있다. 2010년 이스탄 불에서 개최된 Open Forum's Global Assembly에서는 '이스탄불 원칙'을 선언, 제 1조21)에서 시민사회의 역할로 '인권과 사회정의의 실현 및 촉진'을 내세웠다. 또한 2011년 부산 세계개발 원조총회(HLF-4)에서 발표된 '부산결과문서(Busan Outcome Document)'의 제 22조22)는 시 민사회의 '사람들의 권리 주장에 대한 지원, $\mathrm{RBA}$ 촉진, 개발정책 및 파트너십과 그것의 적용 에 대한 감시' 역할을 강조하였다. 개발주체가 전통적인 국가중심의 패러다임에서 시민사회와 민간기업까지 아우르는 포괄적인 방식으로 전환됨에 따라, 향후 시민사회의 역할이 점차 중요 해질 것으로 전망된다.

\section{2. 한국의 사례}

\section{가. 한국 ODA에서의 RBA 정의}

국가인권위원회법은 제 2 조 제1호에서 “인권’이란 「대한민국헌법」 및 법률에서 보장하거 나 대한민국이 가입·비준한 국제인권조약 및 국제관습법에서 인정하는 인간으로서의 존엄과 가치 및 자유와 권리를 말한다”라고 정의하고 있다. 국가인권위원회는 「사회권 실현을 위한 국가인권기구 및 정부의 역할과 과제(2008.3.)」 등의 토론회를 개최하여 국내의 인권보호에 대한 논의의 장을 마련하기도 하였다. 그러나 국가인권위원회, 외교통상부를 비롯한 한국 정 부는 대외적 인권, 특히 $\mathrm{ODA}$ 에 있어서의 인권에 대하여 인식하고 그에 따른 정의를 내린 바 없다.

한편 한국 시민사회는 RBA를 주제로 하여 국제기구나 해외원조단체 또는 국제NGO의 논의 를 중심으로 비교적 활발한 연구가 이루어지고 있는 것으로 보인다. 하지만 관련 논의와 연구 가 산발적으로 진행되는 탓에 한국의 $\mathrm{ODA}$ 에 있어서의 합의된 $\mathrm{RBA}$ 의 정의나 실질적인 활용방 안이 도출되지는 못하고 있다. 또한 시민사회의 $\mathrm{RBA}$ 논의는 $\mathrm{RBA}$ 의 정의나 활용방안보다는 국 제사회의 논의를 정리하는 데 그치는 경우가 많아 외교통상부나 $\mathrm{KOICA}$ 등과 같은 ODA의 주 체들에게 영향력을 미치기 어렵다.

21) Respect and promote human rights and social justice: CSOs are effective as development actors when they develop and implement strategies, activities and practices that promote individual and collective human rights, including the right to development, with dignity, decent work, social justice and equity for all people.

22) CSOs play a vital role in enabling people to claim their rights, in promoting rights-based approaches, in shaping development policies and partnerships, and in overseeing their implementation. 
따라서 이번 절에서는 한국의 $\mathrm{ODA}$ 에 있어서의 $\mathrm{RBA}$ 를 법률(국제법 포함)의 관점으로 임의 로 정의하고자 하며, 이러한 정의는 $\operatorname{Akram}(2011)^{23)}$ 과 일치한다. 이하에서는 KOICA의 ODA 사업을 RBA관점에서 평가하고자 한다. 이를 위해 수원국의 법률, 국제법, 그리고 한국의 법률 을 근거로 하여 사업을 통해 실현할 수 있는 수원국의 권리와 그로 인해 지게 되는 KOICA의 의무를 분석틀로 사용하고자 한다. 단, 여기서의 법률은 연구 자원의 제약으로 한 국가의 헌법 및 세계인권선언 등 최상위 법률로 대부분 한정하였다. 따라서 보다 구체적인 권리 및 의무의 발생 여부 및 그 목록은 해당 수권법률에 대한 후속연구를 통하여 밝혀져야 할 것이다.

\section{나. 한국 $\mathrm{ODA}$ 의 $\mathrm{RBA}$ 환경 분석}

\section{(1) 분석의 틀}

한국의 ODA의 RBA 환경을 분석하기 위하여 Duncan(1972)의 틀을 준용하기로 한다. Duncan(1972)은 환경의 불확실성에 따른 조직설계의 유형을 제시하였는데, 이때의 불확실성 은 변화와 복잡성으로 정의된다. 아래의 〈표 4〉는 이 모델을 도식화한 것이다.

\section{〈표 4〉환경의 불확실성 분석 모델}

\begin{tabular}{|c|c|c|c|}
\hline \multirow{4}{*}{$\begin{array}{c}\text { 환경의 } \\
\text { 변화 }\end{array}$} & \multirow[b]{2}{*}{ 안정 } & 단순+안정=낮은 불안정성 & 복잡+안정=다소 낮은 불안정성 \\
\hline & & $\begin{array}{l}\text { 1. 소수의 서로 유사한 외부요소들 } \\
\text { 2. 변화하지 않거나 천천히 변화 } \\
\text { 하는 요소들 }\end{array}$ & $\begin{array}{l}\text { 1. 다수의 서로 다른 환경 요소들 } \\
\text { 2. 변화하지 않거나, 천천히 변화 } \\
\text { 하는 요소들 }\end{array}$ \\
\hline & \multirow{4}{*}{ 불안정 } & 단순+불안정 $=$ 다소 높은 불안정성 & 복잡+불안정성=높은 불안정성 \\
\hline & & \begin{tabular}{|l} 
1. 소수의, 서로 유사한 외부 요소들 \\
2. 자주, 예상할 수 없이 변화하는 \\
요소들
\end{tabular} & $\begin{array}{l}\text { 1. 다수의, 서로 다른 환경 요소들 } \\
\text { 2. 자주, 예상할 수 없이 변화하 } \\
\text { 는 요소들 }\end{array}$ \\
\hline & & 단순 & 복잡 \\
\hline & & 환경의 & 복잡성 \\
\hline
\end{tabular}

(출처: Duncan, 1972)

본래 이 모델은 조직이 처한 환경을 분석하기 위하여 개발된 모델이지만, 본 연구에서는 한 국의 $\mathrm{ODA}$ 을 둘러싼 $\mathrm{RBA}$ 라는 담론을 하나의 환경으로 파악하였다. 상기한 바와 같이 한국의

23) Akram S., Dumper M., Lynk M., \& Scobbie I. (2011) International Law and the Israeli-Palestinian Conflict. Routledge: NY. 참고. 
$\mathrm{RBA}$ 담론은 일치된 정의조차 없이 다기한 논의들만이 존재하는 상태로서, Duncan의 불확실 한 환경 분석 모델을 준용하는 것이 편리하고도 적절한 것으로 판단하였다. 이 분석모델을 활 용하여 우리는 이 절의 말미에서 한국의 $\mathrm{ODA}$ 이 $\mathrm{RBA}$ 를 어떻게 활용하여야 하는지, 더 나아가 $\mathrm{ODA}$ 사업을 수행하는 조직은 어떤 환경에 처해 있는지에 대한 결론을 얻을 수 있을 것이다.

아래에서는 환경의 변화와 복잡성, 즉 RBA 담론의 변화와 복잡성을 법적측면, 정책적 측면 영역으로 나누어 분석한다. 단, 환경의 불확실성을 평가하는 각각의 측면에 대하여 다음 〈표 5)와 같이 가중치를 정한다.

\section{〈표 5〉 환경의 불확실성 평가 각 측면의 가중치}

\begin{tabular}{|c|c|c|c|}
\hline \multicolumn{2}{|r|}{ 측면 } & 가중치 & 비고 \\
\hline \multirow[t]{2}{*}{ 법 } & 국제법 & 0.35 & $\begin{array}{l}\text { 국제법은 한국의 경우 비준을 통해 국내법으로 편입되어야 } \\
\text { 효력을 갖는다는 점을 고려하여 가중치를 낮춤. 단, 국제법이 } \\
\text { 국내법의 외부환경으로 작용하는 점을 고려하여 정책의 가중 } \\
\text { 치보다는 높은 수치를 부여함. }\end{array}$ \\
\hline & 국내법 & 0.45 & - \\
\hline & 정책 & 0.20 & $\begin{array}{l}\text { 정책의 경우 국내법이 외부환경으로 작용함을 고려하여 가중 } \\
\text { 치를 낮춤. 법률과 정책은 형식만 다를 뿐 본질은 동일하기 } \\
\text { 때문(정정길, 2010) }\end{array}$ \\
\hline
\end{tabular}

(출처: Duncan, 1972)

본 분석에서는 국내법적 측면을 환경의 불확실성에 대한 가장 중요한 요소로 설정하였다. 덧붙여 '변화’란, 격동성 및 불안정성을 요소로 하며 복잡성이란 많은 외부요소의 수 및 그들 의 상이성, 다양성 그리고 이질성을 요소로 한다.

\section{(2) 법적측면}

(1) 국제법

국제법적 측면에서 한국 $\mathrm{ODA}$ 을 둘러싼 RBA 담론환경을 분석하기 위하여 먼저 아래의 〈표 6)과 같이 한국이 비준하여 국내법적으로 효력이 발생한 소위 '인권’ 관련 국제법(다자조약)을 정리하였다. 


\section{〈표 6〉 한국내 발효된 다자조약 목록}

\begin{tabular}{|c|c|c|}
\hline 약 & $\begin{array}{c}\text { 채택일 } \\
\text { (연-월-일) }\end{array}$ & $\begin{array}{l}\text { 한국 발효일 } \\
\text { (연-월-일) }\end{array}$ \\
\hline 장애인의 권리에 관한 협약 & $2006-12-13$ & $2009-01-10$ \\
\hline 아동의 권리에 관한 협약 제9조 제3항 유보 철회 & $1989-11-20$ & $2008-10-16$ \\
\hline $\begin{array}{l}\text { 고문 및 그 밖의 잔혹한 } \cdot \text { 비인도적인 또는 굴욕적인 대우나 처 } \\
\text { 벌의 방지에 관한 협약 제21조 및 제22조 수락선언 }\end{array}$ & $1984-12-10$ & $2008-01-03$ \\
\hline $\begin{array}{l}\text { 시민적 및 정치적 권리에 관한 국제규약 제 } 14 \text { 조 제5항에 대한 } \\
\text { 유보철회 }\end{array}$ & $1966-12-16$ & $2007-04-02$ \\
\hline 여성에 대한 모든 형태의 차별철폐에 관한 협약 선택의정서 & $1999-10-06$ & $2007-01-18$ \\
\hline 아동의 무력충돌 참여에 관한 아동권리협약 선택의정서 & $2000-05-25$ & $2004-10-24$ \\
\hline $\begin{array}{l}\text { 아동 매매·아동 성매매 및 아동 음란물에 관한 아동권리에 관한 } \\
\text { 협약 선택의정서 }\end{array}$ & $2000-05-25$ & $2004-10-24$ \\
\hline 아동의 권리에 관한 협약 제43조 제2항 개정 & $1995-12-12$ & $2002-11-18$ \\
\hline 여성에 대한 모든 형태의 차별 철폐에 관한 협약 제9조 유보철회 & $1979-12-18$ & $1999-08-24$ \\
\hline 모든 형태의 인종차별 철폐에 관한 국제협약 제14조 선언 & & 1997-03-05 \\
\hline $\begin{array}{l}\text { 고문 및 그 밖의 잔혹한, 비인도적인 또는 굴욕적인 대우나 처 } \\
\text { 벌의 방지에 관한 협약 }\end{array}$ & $1984-12-10$ & $1995-02-08$ \\
\hline $\begin{array}{l}\text { 시민적 및 정치적 권리에 관한 국제규약 제14조 제7항에 대한 } \\
\text { 유보철회 }\end{array}$ & & $1993-01-21$ \\
\hline 아동의 권리에 관한 협약 & $1989-11-20$ & $1991-12-20$ \\
\hline $\begin{array}{l}\text { 여성에 대한 모든 형태의 차별 철폐에 관한 협약 제16조 제1항 } \\
\text { (다), (라), (바)호에 대한 유보철회 }\end{array}$ & & $1991-03-15$ \\
\hline $\begin{array}{l}\text { 시민적 및 정치적 권리에 관한 국제규약 제23조 제4항에 대한 } \\
\text { 유보철회 }\end{array}$ & & $1991-03-15$ \\
\hline 시민적 및 정치적 권리에 관한 국제규약 (B규약) & $1966-12-16$ & $1990-07-10$ \\
\hline 경제적, 사회적 및 문화적 권리에 관한 국제규약 (A규약) & $1966-12-16$ & $1990-07-10$ \\
\hline 시민적 및 정치적 권리에 관한 국제규약 선택의정서 & $1966-12-16$ & $1990-07-10$ \\
\hline 여성에 대한 모든 형태의 차별철폐에 관한 협약 & $1979-12-18$ & $1985-01-26$ \\
\hline 모든 형태의 인종차별 철폐에 관한 국제협약 & $1965-12-21$ & 1979-01-04 \\
\hline $\begin{array}{l}\text { 인신매매금지 및 타인의 매춘행위에 의한 착취금지에 관한 협약 } \\
\text { 및 최종의정서 }\end{array}$ & $1950-03-21$ & $1962-05-14$ \\
\hline 부녀자의 정치적 권리에 관한 협약 & 1953-03-31 & 1959-09-21 \\
\hline 집단살해죄의 방지와 처벌에 관한 협약 & 1948-12-09 & 1951-01-12 \\
\hline
\end{tabular}

(출처: 외교통상부 홈페이지에서 발췌 후 재구성) 
i . 환경의 변화 : 위의 표에서 보는 바와 같이 한국은 주요 인권 관련 다자조약을 모두 비 준하였다. 이는 국제법적인 측면에서의 변화는 예측 가능한 것으로, 이러한 측면에서 $\mathrm{RBA}$ 담론환경은 안정적이라 평가할 수 있다.

ii. 환경의 복잡성 : 위의 표와 같은 다양한 인권 관련 다자조약들은, 기대와는 달리 현실에 서는 어떤 것이 인간의 권리이고 의무인지 파악하는데 혼란을 주고 있는 것으로 보인 다. 하지만 향후 국제사회의 법치주의에 대한 옹호의 목소리가 강해질수록, 인권을 위 한 다자조약은 증가할 수밖에 없을 것이고, 그에 따라 한국이 비준하게 될 다자조약 역 시 증가할 것이다. 따라서 $\mathrm{RBA}$ 담론환경은 복잡한 것으로 평가할 수 있다.

(2) 국내법

한국에서 $\mathrm{ODA}$ 과 관련하여 국내법적인 RBA환경을 분석하기 위하여 아래〈표 7〉과 같이 관 련 법률을 정리하였다.

〈표 7〉인권 및 ODA관련 한국 국내 법률 목록

\begin{tabular}{|c|c|c|}
\hline 법률명 & 관련 조 & 내용 \\
\hline \multirow{2}{*}{$\begin{array}{l}\text { 대한민국 } \\
\text { 헌법 }\end{array}$} & 제6조 & $\begin{array}{l}\text { (1)헌법에 의하여 체결·공포된 조약과 일반적으로 승인된 국제법 } \\
\text { 규는 국내법과 같은 효력을 가진다. } \\
\text { (2)외국인은 국제법과 조약이 정하는 바에 의하여 그 지위가 보 } \\
\text { 장된다. }\end{array}$ \\
\hline & 제10조 & $\begin{array}{l}\text { 모든 국민은 인간으로서의 존엄과 가치를 가지며, 행복을 추구 } \\
\text { 할 권리를 가진다. 국가는 개인이 가지는 불가침의 기본적 인권 } \\
\text { 을 확인하고 이를 보장할 의무를 진다. }\end{array}$ \\
\hline \multirow[t]{2}{*}{$\begin{array}{l}\text { 국가인권 } \\
\text { 위원회법 }\end{array}$} & 제1조 & $\begin{array}{l}\text { 이 법은 국가인권위원회를 설립하여 모든 개인이 가지는 불가침 } \\
\text { 의 기본적 인권을 보호하고 그 수준을 향상시킴으로써 인간으로 } \\
\text { 서의 존엄과 가치를 실현하고 민주적 기본질서의 확립에 이바지 } \\
\text { 함을 목적으로 한다. }\end{array}$ \\
\hline & 제4조 & $\begin{array}{l}\text { 이 법은 대한민국 국민과 대한민국의 영역에 있는 외국인에 대 } \\
\text { 하여 적용한다. }\end{array}$ \\
\hline $\begin{array}{l}\text { 국제개발 } \\
\text { 협력 } \\
\text { 기본법 }\end{array}$ & 제3조 & $\begin{array}{l}\text { (1) 국제개발협력은 개발도상국의 빈곤감소, 여성과 아동의 인권 } \\
\text { 향상 및 성평등 실현, 지속가능한 발전 및 인도주의를 실현하고 } \\
\text { 협력대상국과의 경제협력관계를 증진하며 국제사회의 평화와 번 } \\
\text { 영을 추구하는 것을 기본정신으로 한다. }\end{array}$ \\
\hline
\end{tabular}




\begin{tabular}{|c|c|c|}
\hline 법률명 & 관련 조 & 내용 \\
\hline & & $\begin{array}{l}\text { (2) 국제개발협력은 제 } 1 \text { 항의 기본정신을 추구하기 위하여 다음 } \\
\text { 각 호의 사항을 달성하는 것을 목표로 한다. } \\
\text { 1. 개발도상국의 빈곤감소 및 삶의 질 향상 } \\
\text { 2. 개발도상국의 발전 및 이를 위한 제반 제도·조건의 개선 } \\
\text { 3. 개발도상국과의 우호협력관계 및 상호교류 증진 } \\
\text { 4. 국제개발협력과 관련된 범지구적 문제 해결에 대한 기여 } \\
\text { 5. 그 밖에 제 } 1 \text { 항의 기본정신을 달성하기 위하여 필요하다고 인 } \\
\text { 정되는 사항 }\end{array}$ \\
\hline & 제4조 & $\begin{array}{l}\text { (1) 국가, 지방자치단체, 그 밖의 시행기관(이하 "국가등"이라 한 } \\
\text { 다)은 국제개발협력을 실시함에 있어서 다음 각 호의 원칙과 우 } \\
\text { 리나라의 대외정책을 종합적으로 고려하여 추진하여야 한다. } \\
\text { 1. 국제연합헌장의 제반 원칙 존중 } \\
\text { 2. 협력대상국의 자조노력 및 능력 지원 } \\
\text { 3. 협력대상국의 개발 필요 존중 } \\
\text { 4. 개발경험 공유의 확대 } \\
\text { 5. 국제사회와의 상호조화 및 협력 증진 }\end{array}$ \\
\hline & 제5조 & $\begin{array}{l}\text { (1) 국가등은 제 } 1 \text { 조의 목적과 제3조의 기본정신 및 목표 등을 고 } \\
\text { 려하여 국제개발협력 사업을 추진하여야 한다. } \\
\text { (2) 국가등은 개발도상국의 빈곤퇴치 및 지속가능한 발전을 위한 } \\
\text { 국제사회의 노력에 동참하고 이를 위하여 적극적인 역할을 수행한다. }\end{array}$ \\
\hline \multirow[b]{2}{*}{$\begin{array}{c}\text { 한국 } \\
\text { 국제 } \\
\text { 협력단법 }\end{array}$} & 제1조 & $\begin{array}{l}\text { 이 법은 대한민국과 개발도상국가와의 우호협력관계 및 상호교 } \\
\text { 류를 증진시키고 개발도상국가의 경제·사회발전을 지원하기 위 } \\
\text { 하여 한국국제협력단을 설립하여 각종 협력사업을 하게 함으로 } \\
\text { 써 국제협력 증진에 이바지함을 목적으로 한다. }\end{array}$ \\
\hline & 제7조 & $\begin{array}{l}\text { 협력단은 제 } 1 \text { 조의 목적을 달성하기 위하여 다음 각 호의 사업을 한다. } \\
\text { 1. 개발도상국가를 위한 다음 각 목의 사업 } \\
\text { 가. 연수생의 초청 } \\
\text { 나. 전문인력의 파견 } \\
\text { 다. 해외봉사단의 파견 } \\
\text { 라. 개발조사 } \\
\text { 마. 재난구호 } \\
\text { 바. 물자·자금 및 시설의 지원 } \\
\text { 2. 국제협력을 위한 다음 각 목의 사업 } \\
\text { 가. 민간단체의 국제협력환동에 대한 지원 } \\
\text { 나. 외국의 원조 관련 기관 및 국제기구와의 협력 } \\
\text { 다. 국제협력에 관한 이념 및 정책의 수립 등을 위한 조사.연구 } \\
\text { 라. 그 밖에 국제협력의 증진을 위하여 필요한 사업 } \\
\text { 3. 정부가 위탁하는 사업 }\end{array}$ \\
\hline
\end{tabular}

(출처: 저자 작성) 
i . 환경의 변화: 헌법은 국내규범성, 최고규범성 및 정치성이라는 세 개의 개념요소를 갖 고 있다. 또한 헌법은 자국민이 국제공동체에 편입될 수 있도록 제도적으로 지원하는 한편 외 국인이 국내공동체에 편입되는 데 있어 불이익을 받지 않도록 국제공동체에 우호적인 이념 및 제도를 형성하여야 한다(전광석, 2010). 이러한 의미에서 한국의 헌법이 한국의 개발협력에 가지는 의미는 각별하다 할 것이며, 헌법의 규범성이 수권법률에 의하여 담보되는 한계가 있 다 하더라도 헌법의 최고규범성을 고려할 때 그 의미가 퇴색되지는 않는다고 본다.

세부적으로 살펴보면, 한국의 1987 년 제 9차 개정 헌법은 동법 제 6조와 제 10 조를 통하여 모든 국민의 인권을 확인하고, 그에 대한 국가의 보장 의무를 규정하였다. 더불어, 헌법에 의 하여 체결·공포된 조약 및 일반적으로 승인된 국제법규는 국내법과 같은 효력을 가진다고 규 정하여 UN헌장, 세계인권선언 및 국제인권규범의 국내법적 효력을 보장하였다.

한편 헌법의 수권규범들에 대하여 살펴보자면, 한국은 국가인권위원회법 제 1 조 및 제 4조 를 통하여 모든 개인의 불가침의 인권을 재확인하고 속지주의 원칙을 천명하였다. 국가인권위 원회법은 이와 같이 한국에 거주하는 한국국적자 및 외국국적자에 대한 인권을 확인하고 그에 대한 국가의 의무를 규정하고 있다. 국제개발협력기본법은 제 3 조 내지 제 5 조를 통하여 이러 한 인권의 존재와 그에 대한 국가의 보장의무를 개발도상국을 포함한 국제사회로 확장하고 있 다. 마지막으로 한국은 한국국제협력단법 제 1 조 및 제 7 조를 통하여 상기 국제개발협력기본 법의 규정을 구체화하고 있다.

요약하면, 국내법적 측면에서 한국의 개발협력을 둘러싼 RBA담론환경은 한국의 법치주의 확립과 체계적인 규범성으로 안정적이라 평가할 수 있다.

ii. 환경의 복잡성: 상기한 바와 같이 헌법을 정점으로 한 인권 및 RBA 국제협력사업의 국 내법적 환경은 관련법령의 계층적이고도 유기적인 구조로 인하여 그 수가 많지 않고 서로 상 이하지 않으며 다양성 및 이질성의 정도가 낮다는 접에서 복잡성이 낮다고 평가할 수 있다.

\section{(3) 정책적 측면}

한국정부는 인권과 관련한 대내적 정책은 국가인권위원회를 통하여, 대외적 정책은 외교통 상부를 통하여 결정 및 집행하고 있다. 특히 외교통상부는 국제개발협력기본법 제 9조 제 1항 에 의하여 대외무상협력을 주관하고 있으므로, 후자의 인권 정책에 대하여 간략히 개괄해 보 
고자한다24).

(1) UN

한국은 UN인권이사회 및 UN총회활동을 통하여 인권외교정책을 결정하고 집행하고 있다. 1993년부터 2006년까지는 UN인권위원회(Commission on Human Rights)의 위원국이었으 며, 2006년 설립된 UN인권이사회(Human Rights Council)의 이사국으로 선출된 바 있다. 이 러한 UN인권이사회에서 한국은 여성, 아동, 장애인 등의 분야별 인권 이슈와 함께 북한, 미얀 마 등의 국가별 인권 이슈에 대해서 정책형성에 기여하였다.

(2) 분야별

i. 아동의 인권 : 한국은 $\mathrm{UNICEF}$ 의 집행이사국으로 $\mathrm{UNICEF}$ 의 정책수립 및 개발도상국 아동지원사업에 기여하고 있다. 또한 한국은 2004년부터 매년 한-UNICEF 양자협의회를 가 지고 있으며 2009년에는 한-UNICEF 협정을 체결한 바 있다.

ii. 여성의 인권 : 한국은 상기한 바와 같이 「여성에 대한 모든 형태의 차별철폐에 관한 국 제협약(1979)」를 비준하여 여성의 인권을 인정하기 위한 초석을 닦았다. 현재 한국 국내법에 서 남녀평등의 헌법이념을 가장 전면적으로 구현하고 있는 것은 1988년 제정된 「남녀고용평 등법」을 바탕으로 2007년 개정된 「남녀고용평등과 일·가정 양립 지원에 관한 법률」이다. 동 법률은 제 1 조에서 '이 법은 「대한민국헌법」의 평등이념에 따라 고용에서 남녀의 평등한 기 회와 대우를 보장하고 모성보호와 여성고용을 촉진하여 남녀고용평등을 실현함과 아울러 근로 자의 일과 가정의 양립을 지원함으로써 모든 국민의 삶의 질 향상에 이바지하는 것을 목적으 로 한다라고 규정하여 주로 고용에 있어서의 남녀평등을 목표로 하고 있으나, 실질적으로 남 녀평등 그리고 여성의 인권 향상을 위한 준거법으로 작용하고 있다.

한편 $\mathrm{ODA}$ 에 있어 한국은 $\mathrm{KOICA}$ 를 중심으로 하여 여성의 인권을 ODA전략에 통합시키고자 연구를 진행 중이다. 이에 따라 $\mathrm{KOICA}$ 에는 젠더담당관(Gender Desk)이 지정되어 운영 중이 며, 정책기획부 사회개발팀 소속의 젠더전문관이 활동 중이다.

24) 본 내용은 외교통상부 홈페이지(http://www.mofat.go.kr)의 내용을 기초로 하여 작성된 것임. 
〈그림 1〉 KOICA 양자ODA 사업비 대비 젠더사업비 실적추이

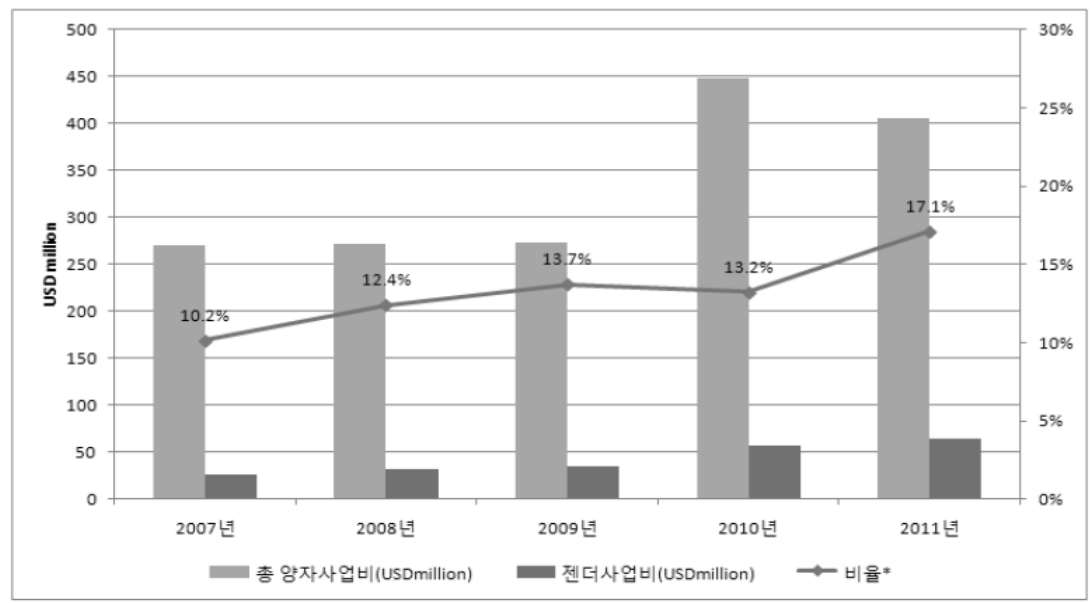

*비율: 총 양자사업비에서 행정성경비를 제외한 금액 중 젠더마커가 부여된 사업비의 비율 ** OECD/DAC 젠더마커1 혹은 2 가 부여된 사업으로 성평등에 직.간접적으로 기여하는 사업

(출처: 오은정, 2012)

이에 따라 KOICA 양자 ODA 사업비 대비 젠더사업비는 위의 〈그림 1〉에서 볼 수 있는 바와 같이 상승추세에 있으며, 이러한 추이는 한국 $\mathrm{ODA}$ 에의 $\mathrm{RBA}$ 활용의 가능성에도 긍정적으로 작 용할 것으로 보인다.

iii. 난민의 인권 : 한국은 위에서 살펴본 바와 같이「 1951 년 난민의 지위에 관한 협약」 및 「1967년 난민의 지위에 관한 의정서」에 가입하였고, 2001년부터 난민을 인정하기 시작하여 누계 235 인 남짓의 난민신청자에게 난민지위를 부여하였다. 또한 한국은 2000 년부터 UNHCR 의 집행이사국으로 활동하였으며, 2001년에는 UNHCR 주한대표부가 서울에 설치되었다.

iv. 장애인의 인권 : 한국은 위에서 살펴본 바와 같이 「2006년 장애인의 권리에 관한 협 약」을 비준하였으며, 특히 여성장애인 조항(제6조)를 별도로 규정한 바 있다.

(3) 소결

i . 환경의 변화: 격동성 및 불안정성을 요소로 하는 변화의 측면에서 볼 때, 외교통상부는 위와 같이 일관적이고 안정적인 국제 인권에 관한 외교정책을 가지고 있는 것으로 보인다. 따 라서 한국의 $\mathrm{ODA}$ 에 있어서의 $\mathrm{RBA}$ 담론의 환경은 안정적인 것으로 평가된다. 
ii. 환경의 복잡성: 외교통상부의 인권정책과 관련하여, 외교통상부는 국제기구와의 협력 및 다자조약의 비준의 측면에서 주로 접근하고 있으며, 국내외 민간단체와의 의사교류는 많지 않은 것으로 나타났다. 단적인 예로, 최근 외교통상부와 민간단체와의 인권에 관한 논의는 주 로 북한에 관한 것이었으며, 그나마 북한과 한국과의 특수한 관계로 인해 실제 외교통상부가 북한의 인권에 대해 취할 수 있는 정책 의사결정의 폭은 넓지 않은 것이 현실이다. 이러한 점 을 감안하였을 때, 정책의 측면에서 한국의 $\mathrm{ODA}$ 에 있어서의 $\mathrm{RBA}$ 담론의 환경은 복잡하지 않 은 것으로 평가된다.

(4) 소결

이상과 같은 분석을 통하여 한국의 $\mathrm{ODA}$ 를 둘러싼 $\mathrm{RBA}$ 담론 환경의 불확실성을 결론하여 보면 아래의 그림과 같다.

〈표 8〉 한국의 ODA의 RBA담론 환경 분석결과

\begin{tabular}{|c|c|c|c|}
\hline \multirow{5}{*}{$\begin{array}{l}\text { 환경의 } \\
\text { 변화 }\end{array}$} & \multirow{2}{*}{ 안정 } & $\begin{array}{c}\text { 단순+안정=낮은 불안정성 } \\
(0.65)\end{array}$ & $\begin{aligned} \text { 복잡 }+ \text { 안정=다소 낮은 불안정성 } \\
(0.35)\end{aligned}$ \\
\hline & & $\begin{array}{l}\text { 국내법적 측면(0.45) } \\
\text { 정책적 측면(0.20) }\end{array}$ & 국제법적 측면(0.35) \\
\hline & \multirow[t]{3}{*}{ 불안정 } & $\begin{array}{c}\text { 단순+불안정 }=\text { 다소 높은 } \\
\text { 불안정성 } \\
(0.00)\end{array}$ & $\begin{array}{c}\text { 복잡+불안정성=높은 불안정성 } \\
(0.00)\end{array}$ \\
\hline & & 단순 & 복잡 \\
\hline & & 환경 & 복잡성 \\
\hline
\end{tabular}

(출처: 저자 작성)

즉 총점 0.65 점으로 한국의 국제개발협력을 둘러싼 $\mathrm{RBA}$ 담론 환경은 낮은 불안정성을 가지 고 있다고 평가할 수 있다. 즉, 한국의 ODA 사업을 수행하는 정부 및 $\mathrm{KOICA}$ 는, RBA담론이 라는 환경의 측면에서 소수의 서로 유사한 외부요소들에 둘러싸여 있으며, 변화하지 않거나 변화한다 하여도 천천히 변화하는 요소들을 마주하고 있다고 할 것이다. 
이러한 환경에서 정부 및 $\mathrm{KOICA}$ 는 (1) 기계적구조(공식적, 집권적) (2) 적은 부서의 수 (3) 통 합수행 역할이 없음 (4) 현재 수행하는 업무 중심(낮은 반응속도)을 조직원리로 하여야 할 것이 다. 다만 국제법적 측면을 고려하여 국제업무를 위하여는 (1) 기계적구조(공식적, 집권적) (2) 많은 부서의 수(경계관리 활동 부서도 약간 존재) (3) 통합수행 역할이 약간 있음(보통의 반응 속도)을 해당 업무 조직을 위한 원리로 고려할 수 있을 것이다.

한국의 $\mathrm{ODA}$ 가 $\mathrm{RBA}$ 를 어떻게 활용할지에 관하여는, 다음으로 $\mathrm{KOICA}$ 사례를 살펴본 후 결 론지을 수 있을 것이다.

\section{다. KOICA 사례}

(1) 한국의 $\mathrm{ODA}$ 의 RBA활용방안

(1) 분석의 틀 및 정책의 유형 결정

Ripley와 Franklin(1986)은 정책유형을 배분(distributive)정책, 재분배(redistributive), 규제(regulatory)정책으로 나누고 규제정책을 다시 경쟁적(competitive)규제정책과 보호적 (protective)규제정책으로 나누면서 이러한 정책유형별 정책집행의 차이를 제시하였다. 본 이 론을 표로 정리하면 아래와 같다.

\section{〈표 9〉 Ripley와 Franklin의 정책유형}

\begin{tabular}{|c|c|c|c|c|c|c|c|}
\hline $\begin{array}{l}\text { 비교 } \\
\text { 기준 } \\
\text { 정책 } \\
\text { 유형 }\end{array}$ & $\begin{array}{l}\text { 안정적인 } \\
\text { 루틴의 } \\
\text { 확립을 통한 } \\
\text { 원만한 집행 } \\
\text { 가능성 }\end{array}$ & $\begin{array}{c}\text { 주요 } \\
\text { 관련자들의 } \\
\text { 동일성과 } \\
\text { 그들간 관계의 } \\
\text { 안정성 } \\
\end{array}$ & $\begin{array}{l}\text { 집행에 } \\
\text { 대한 } \\
\text { 논쟁과 } \\
\text { 갈등의 } \\
\text { 정도 }\end{array}$ & $\begin{array}{l}\text { 관료의 집행 } \\
\text { 결정에 대한 } \\
\text { 반발의 정도 }\end{array}$ & $\begin{array}{c}\text { 집행을 } \\
\text { 둘러싼 } \\
\text { 논쟁에 있어 } \\
\text { 이데올로기 } \\
\text { 의 논쟁정도 }\end{array}$ & $\begin{array}{l}\text { 정부활동의 } \\
\text { 감소를 위한 } \\
\text { 압력의 정도 }\end{array}$ & $\begin{array}{l}\text { 성공적인 } \\
\text { 집행의 } \\
\text { 상대적 } \\
\text { 어려움 }\end{array}$ \\
\hline 분배정책 & 높다 & 높다 & 낮다 & 낮다 & 낮다 & 낮다 & 낮다 \\
\hline $\begin{array}{l}\text { 경쟁적 } \\
\text { 규제정책 }\end{array}$ & 보통이다 & 낮다 & 보통이다 & 보통이다 & $\begin{array}{c}\text { 어느정도 } \\
\text { 높다 }\end{array}$ & $\begin{array}{c}\text { 어느정도 } \\
\text { 높다 }\end{array}$ & 보통이다 \\
\hline $\begin{array}{l}\text { 보호적 } \\
\text { 규제정책 }\end{array}$ & 낮다 & 낮다 & 높다 & 높다 & 높다 & 높다 & 보통이다 \\
\hline 재분배정책 & 낮다 & 높다 & 높다 & 높다 & 매우 높다 & 높다 & 높다 \\
\hline
\end{tabular}

(출처: Ripley R. \& Franklin G., 1986) 
위에서 본 것과 같이 한국 $\mathrm{ODA}$ 의 $\mathrm{RBA}$ 환경은 낮은 불안정성을 가지고 있다. 이에 따라 위 의 분석의 틀에서의 비교기준에 대해 평가해 보면 다음과 같은 결과를 얻을 수 있다.

〈표 10〉Ripley와 Franklin의 정책유형에 기초한 한국 ODA의 RBA환경분석 결과

\begin{tabular}{|c|c|c|c|c|c|c|c|}
\hline $\begin{array}{l}\text { 비교 } \\
\text { 기준 }\end{array}$ & $\begin{array}{l}\text { 안정적인 } \\
\text { 루틴의 } \\
\text { 확립을 통한 } \\
\text { 원만한 집행 } \\
\text { 가능성 }\end{array}$ & $\begin{array}{c}\text { 주요 } \\
\text { 관련자들의 } \\
\text { 동일성과 } \\
\text { 그들간 관계의 } \\
\text { 안정성 }\end{array}$ & $\begin{array}{l}\text { 집행에 } \\
\text { 대한 } \\
\text { 논쟁과 } \\
\text { 갈등의 } \\
\text { 정도 }\end{array}$ & $\begin{array}{l}\text { 관료의 집행 } \\
\text { 결정에 대한 } \\
\text { 반발의 정도 }\end{array}$ & $\begin{array}{c}\text { 집행을 } \\
\text { 둘러싼 } \\
\text { 논쟁에 있어 } \\
\text { 이데올로기 } \\
\text { 의 논쟁정도 }\end{array}$ & $\begin{array}{c}\text { 정부활동 } \\
\text { 의 감소를 } \\
\text { 위한 } \\
\text { 압력의 } \\
\text { 정도 }\end{array}$ & $\begin{array}{c}\text { 성공적인 } \\
\text { 집행의 } \\
\text { 상대적 } \\
\text { 어려움 }\end{array}$ \\
\hline 분배정 & 높다 & 높다 & 낮다 & 낮다 & & 낮다 & 낮다 \\
\hline
\end{tabular}

(출처: 저자 작성)

상기 결과는 음영처리한 부분을 제외하면 ODA가 분배정책의 유형으로 분류될 수 있음을 보 여준다. '집행을 둘러싼 논쟁에 있어 이데올로기의 논쟁정도'는 무상원조와 유상원조, 분절화 및 통합을 둘러싼 정부 및 하부기관의 헤게모니 다툼을 고려하여 보통 수준으로 평가되었다.

이상의 분석에 따르면 $\mathrm{ODA}$ 정책은 분배정책으로서, $\mathrm{ODA}$ 사업에 대한 $\mathrm{RBA}$ 의 적용은 분배정 책의 특성에 따라 이루어지면 될 것으로 보인다. 하지만 현실적으로 한국의 ODA에 RBA가 본 격적으로 적용되어 사업이 시행된 사례를 찾아보기 힘든 것이 현실이다. 따라서 아래에서는 실제 RBA가 활용될 수 있는 $\mathrm{KOICA}$ 의 ODA사업의 예를 살펴보고, 한국의 ODA에서 RBA가 활용되지 못한 이유를 먼저 살펴보고자 한다. 그리고 한국의 ODA정책을 분배정책으로 분류할 때 $\mathrm{RBA}$ 활용방안은 어떤 모습이 되어야 하는지, 우선 무상협력사업을 주로 수행하고 있는 $\mathrm{KOICA}$ 에 대한 제언의 형식으로 마무리 하고자 한다.

(2) 사례 1 - 베트남 해외사무소의 현지고용원 관리내규 수립

(1) 개요

$\mathrm{KOICA}$ 베트남 해외사무소는 베트남 국적의 직원 고용에 관한 내규를 수립하여 그들의 근 로의 대가를 받을 권리, 공정한 근로조건에 관한 권리 및 휴식과 여가에 관한 권리를 포함하는 근로의 권리를 기초로 근로계약을 행하였다. 또한 이를 통하여 근로자에 대한 임금지급의무, 균등대우의무 등을 포함한 사용자의 의무를 준수하였다. 
(2) 관련 규범

i. 세계인권선언 제 23 조 및 제 24 조

ii. 베트남 사회주의공화국 헌법 제 55 조 내지 제 58 조 및 노동관련법령

iii. 대한민국 헌법 제32조 및 제33조 및 노동관련법령

(3) 평가

$\mathrm{KOICA}$ 베트남 해외사무소의 현지고용원 관리내규의 수립은 KOICA의 베트남 내에서의 사 업규모 확대에 따라 $\mathrm{KOICA}$ 해외봉사단 사무소 인력을 포함하여 베트남 국적의 근로자의 고용 이 꾸준히 증가함에 따른 것이다. $\mathrm{KOICA}$ 베트남 해외사무소는 이 관리내규를 통하여 베트남 국적의 근로자를 합법적으로 채용함은 물론, 객관적인 근무평가 제도를 마련하여 베트남 국적 의 근로자들이 능력과 성과에 따른 합리적인 처우를 받을 수 있는 기반을 마련한 데에 그 의의 가 있다.

$\mathrm{KOICA}$ 베트남 해외사무소의 현지고용원 관리내규의 수립은 RBA의 원칙을 의식하고 시행 한 활동은 아니다. 하지만 결과적으로 $\mathrm{KOICA}$ 는 이를 통하여 협력국인 베트남 국민의 권리와 공여국인 한국의 의무를 정의 및 보장하게 되었다.

(3) 사례 2 - 도미니카 공화국 미성년 임신방지 사업 및 여성보건환경 개선사업(2008-2011)

(1) 개요(한국국제협력단, 2011)

도미니카 공화국 청소년 임신 및 출산율 통계에 따르면 10 대 여자 청소년의 $23 \%$ 가 이미 임 신이나 출산을 경험하였고, 임산부의 $1 / 4$ 이 $15-19$ 세의 청소년들이다. 도미니카 공화국의 청 소년 성관계 연령은 점점 낮아지고 있으며, 가톨릭국가의 사회분위기 등을 고려할 때, 기존 학 교 교육과정에 성교육을 포함하기 어려운 실정이다.

이에 따라 $\mathrm{KOICA}$ 는 도미니카공화국 여성부화 함께 청소년 성생식보건(Sexual and Reproductive Health)센터에서 청소년들로 하여금 올바른 성인지적 관점을 정립할 수 있도록 교육사업을 시행하였다. 교육내용은 여성 청소년 교육자 교육, 청소년 보건지도자 양성 등 6 개 주제이다. 특히 청소년 성에 대한 대중 인식을 변화시키지 않고서는 청소년 임신 및 낙태율 을 감소시키기 어렵다는 인식아래 사업 착수 시점부터 TV 및 라디오 등 대중매체를 통해 성에 
대한 대중인식을 제고하였다.

(2) 관련규범

$\mathrm{i}$. 세계인권선언 제 2 조, 제 3 조, 제 25 조제 2 항, 제 26 조제 1 항 및 동조제 2 항

ii. 도미니카공화국 헌법 제 1 조 및 제 13 조

iii. 대한민국 헌법 제 12 조, 제 31 조, 제 34 조 및 제 36 조

(3) 평가

본 사업에서 가장 특징적인 부분은 미성년 및 성인 여성의 보건을 그들의 권리로 보았다는 점이다. 일례로 $\mathrm{UNIFEM}^{25}$ )의 보고에 따르면, 2000 년도 116 명의 인도의 에이즈 감염자를 대 상으로 조사한 결과 58명의 여성은 결혼 전 성(性)에 관해 무지한 것으로 나타났다. 이러한 터 부에 따라 여성들은 에이즈 감염에 취약해지고 감염된 여성의 경우에는 사회로부터 배척되는 악순환이 반복된다는 것이다.

본 사업에서는 여성들의 높은 임신 및 낙태율의 원인이 해당 여성들의 보건권 및 교육권의 박탈에서 비롯된 것이라 판단하였다. 따라서 미성년 및 성인 여성들에 대한 교육을 통해 그들 의 권리를 확립하고, 한국과 도미니카공화국의 정부가 그들에 대하여 가지고 있는 의무를 정 립하였다. 이러한 RBA를 활용한 $\mathrm{ODA}$ 사업이 본 사업의 높은 성과로 이어진 것이다.

\section{라. 한국 ODA에 RBA가 활용되지 못하였던 이유 - 무의사결정론을 중심으로}

\section{(1) 한국 ODA에 있어서의 엘리트의 정의}

Bachrach와 Baratz(1962)가 주장한 무의사결정론(Non-decision Making)의 '엘리트' 개념 과 관련하여, 한국의 ODA에 있어서의 엘리트는 외교통상부를 중심으로 한 정부 및 $\mathrm{KOICA}$ 의 소속직원 및 그 정책결정에 관여하는 정계 및 학계 관계자로 정의한다.

\section{(2) 한국 $\mathrm{ODA}$ 에 있어서의 무의사결정 과정}

한국의 $\mathrm{ODA}$ 에 있어서 엘리트는 $\mathrm{RBA}$ 를 과거 한국 개발과정에서의 '저항적 개념으로서의 인

25) 바스피아(2007), $R B A$ 핸드북. 바스피야: 서울. 참고 
권'으로 파악하여 RBA의 도입에 대해 민감하게 반응하는 경향이 없지 않다. 이러한 사실은 2012년 한국에 대한 UN인권이사회 '국가별 정례인권검토(Universal Periodic Review)'를 앞 두고 한국정부가 보고서를 작성하는 과정에서의 사례에서도 찾아볼 수 있다. 참여연대를 비롯 한 시민단체들은 의사표현의 자유, 집회결사의 자유, 사형제도 폐지, 양심적 병역거부, 난민 권리 보호, 이주민에 대한 차별 개선, 여성 인권, 아동 및 청소년 인권, 성적지향을 포함한 차 별금지법 제정, 개인정보보호 등 분야별 검토 권고사항을 이행할 것을 한국정부에 요구한 바 있다. 이후 한국정부는 국가인권위원회법을 제정하는 등 인권담론의 공론화에 힘쓰기도 하였 으나, 적극적으로 수용하는 모습은 보이지 않았다는 시각들도 있다. 이러한 한국정부의 인권 이슈에 대한 무의사결정은 $\mathrm{ODA}$ 정책에도 그대로 이어져, 외교통상부나 KOICA 모두 ODA정책 에 RBA가 도입되는 것을 무의사결정하여 온 것으로 보인다.

\section{(3) 한국 $\mathrm{ODA}$ 에 있어서의 무의사결정 수단}

Bachrach와 Baratz(1962)는 무의사결정수단으로 '폭력', '권력', '편견의 동원' 그리고 '편견 의 수정' 및 강화라는 네 가지 수단을 제시하였다. 한국의 ODA에 있어서의 엘리트는 이 중 주 로 '편견의 동원' 방법을 사용한 것으로 판단된다. 이것은 $\mathrm{ODA}$ 정책이 '분배정책'이라는 특징에 서도 기인하는데, 엘리트는 $\mathrm{ODA}$ 정책 의사결정과정이나 집행과정 등 전 영역에 걸쳐 법령과 기존의 절차를 강조하는 방법으로 $\mathrm{RBA}$ 의 도입을 무의사결정하였다.

\section{마. 소결 : $\mathrm{KOICA}$ 의 $\mathrm{ODA}$ 의 RBA 도입 및 활용방안}

위에서 살펴본 바와 같이 KOICA의 ODA에 RBA가 도입되지 못한 것은 한국 ODA 엘리트의 무의사결정에 따른 것이며, 그 사용수단은 비교적 온건한 것이었다고 할 수 있다. 따라서 그 사용수단의 성격을 감안할 때, 한국 ODA에의 RBA도입은 기존의 지배적 규범(법률)이나 제도 적 과정(절차)등을 활용하는 방안이 되어야 함을 알 수 있다. 이 방안은 KOICA 외부적으로는 법률의 형태를 띨 것이며, KOICA 내부적으로는 '표준운영절차(SOP)'의 형태를 가질 것이다.

여기서 '분배정책'이란 정부가 재정, 권리, 지위, 기회, 서비스 등을 불특정다수에게 제공하 여 주는 것이며, 재원은 원칙적으로 조세와 같은 공공재원이다. 따라서 KOICA가 ODA정책을 집행함에 있어 $\mathrm{RBA}$ 를 활용하고자 할 때 그 재원은 현재와 같이 공공재원이어야 한다.

분배정책은 수혜자 집단간 윈윈정책의 성격을 띠고 있다. 따라서 환경으로부터의 저항보다 
는 순응도가 매우 높으며 저항이 적어 정책의 자율성은 그만큼 높다. 따라서 KOICA ODA정책 을 집행함에 있어 협력업체나 국민으로부터 저항을 받을 가능성은 매우 낮다. 이러한 점은 국 민들에 대한 인식조사에서의 $\mathrm{KOICA}$ 사업에 대한 호의적인 결과를 보아도 증명된다. 그러므로 $\mathrm{KOICA}$ 는 $\mathrm{ODA}$ 사업을 집행함에 있어 외교통상부와 함께 $\mathrm{RBA}$ 활용에 관한 표준운영절차 $(\mathrm{SOP})$ 를 정립하여 운영하여야 하며, 나아가 국제개발협력기본법 및 한국국제협력단법에도 $\mathrm{RBA}$ 를 사업에 활용함을 명기하는 것이 필요하다.

유의할 점은 분배정책은 혜택이 다수에게 분산된다는 점에서 '로그롤링(log-rolling)26)' 또 는 '포크배럴(pork barrel)27)'현상이 생긴다는 것이다. 따라서 KOICA는 한국 국민 또는 협력 대상국의 국민에게 혜택이 공정하게 돌아갈 수 있도록 청렴 및 반부패 장치에 역점을 두어 $\mathrm{RBA}$ 활용에 관한 표준운영절차(SOP)를 정립하여야 할 것이다.

또한 분배정책은 능률성이나 효과성을 추구하며 재원의 일차적 배분으로서 기회균등을 전 제로 각자의 노력에 따라 수혜의 정도가 달라진다. 따라서 $\mathrm{KOICA}$ 는 자유주의 사상에 근거하 여 $\mathrm{RBA}$ 활용에 관한 표준운영절차( $\mathrm{SOP})$ 를 마련하여야 한다. 즉 권리와 의무를 계약의 관점에 서 바라보고, $\mathrm{RBA}$ 활용에 관한 표준운영절차 $\mathrm{SOP}$ )에 따라 $\mathrm{ODA}$ 정책이 집행될 때 성과관리가 반드시 필요하다는 것이다.

\section{제3장 정책제언}

앞서 살펴본대로, 한국은 인권과 관련한 기본적인 국제조약을 비준하고 있고 국내법도 갖추 고 있으나, 이는 국내의 인권을 대상으로 하고 있으며 국제사회, 특히 대(對)개도국 인권보호 에 대한 인식과 법적·제도적 장치는 미비한 실정이다. 따라서 $\mathrm{RBA}$ 활용에 관한 표준운영절차 $(\mathrm{SOP})$ 를 정립하기 위해서는 먼저, 범국가적인 차원에서의 $\mathrm{ODA}$ 철학과 목적에 대한 정립이 우선되어야 한다. 이것이 한국의 「ODA 백서」제작이 선행되어야 하는 이유이다. 「ODA 백 서」란 한 국가의 대외원조에 대한 목적과 철학 및 이를 위한 실행계획 등이 담겨있는 최상위 개념의 기본서로서, 이를 기조로 개발협력의 주체들(각 정부부처 및 지자체, 민간부문 전체)은

26) 이권(利權)이 결부된 몇 개의 법안을 관련 의원들이 서로 협력해서 통과시키는 행태를 가리키는 미국의 의회 용어다. 개척자가 벌채한 통나무를 운반하면서 서로 협력해 굴리기를 한 데서 유래했다. (주: 네이버 지식백과)

27) 이권법안(利權法案) 또는 이권법안을 둘러싸고 벌어지는 정치게임을 지칭하는 말이다. 원래의 뜻은 ‘돼지고기 통’으로, 이권 또는 정책 교부금을 얻으려고 모여드는 의원들이 마치 남부의 농장에서 농장주가 돼지고기 통에서 한 조각의 고 기를 던져 줄 때 모여드는 노예와 같다는 뜻에서 나온 말이다. (주: 네이버 지식백과) 
백서에서 제시한 방향과 계획에 따라 일관되고 통일된 목표를 향해 각자의 개발협력을 추진하 는 것이다. 따라서, 정치적·외교적·경제적·전략적인 판단에 입각한 국익을 면밀히 따져본 후 한국 $\mathrm{ODA}$ 에 목적과 철학에 따라 RBA 도입 여부를 결정해야 할 것이다.

본 연구에서는 한국이 향후 선진국으로서 국제사회의 모범이 되는 국가로 발돋움하기 위해 서는 먼저 국제사회의 기본 규범을 준수해야한다는 시각에 근거하여, 한국 $\mathrm{ODA}$ 에 RBA 도입 을 위한 방안을 다음과 같이 제시하고자 한다.

\section{1. 범정부 차원에서의 조치 방안}

\section{가. 강한 정치적·정책적 의지의 확립}

인권에 관한 담론은 근본적으로 정치적일 수밖에 없다. 따라서 $\mathrm{RBA}$ 의 성공을 위해서는 대 통령과 외교부장관 등 정부 수뇌부와 정치권을 비롯하여, $\mathrm{ODA}$ 수행기관 지도층의 강력한 의 지가 필요하다. 이는 인권 위반사항 발생시, 이를 규제 및 처벌할 의지까지 포함하는데, 한국 국적의 글로벌기업 등도 감시의 대상에 포함시키기 때문에 반대세력으로부터의 압박에도 굴하 지 않을 강한 의지 및 정책이 필요한 것은 이 때문이다.

\section{나. 관련 법규의 제정}

상기의 강한 정치적 의지를 실현시킬 방안으로 가장 효과적인 것이 관련 법규의 제정 및 시 행이다. 2011년 10월 시행된 우리나라 「국제개발협력기본법」 제 3조 1항에서 '여성과 아동의 인권향상 및 성평등 실현'에 대해 언급하고는 있으나, RBA에 초점을 둔 법조문은 없다고 할 수 있다. $\mathrm{RBA}$ 를 위한 법규 혹은 법조문이 필요한 이유는 특히 다음과 같은 이유 때문이다.

(1) RBA 예산의 확보 : 정부의 ODA관련 예산 (무·유상 통합)에 있어서 RBA를 위한 예산을 별도로 확보할 필요가 있다. 이는 별도 $\mathrm{RBA}$ 를 위한 개발프로그램 실시를 위한 것도 있지만, $\mathrm{RBA}$ 도입을 위한 기본 인프라 (인권전문가 양성을 위한 교육, $\mathrm{R} \& \mathrm{D}$ 및 인식제고 등) 확충을 위해 필요한 자금을 의미한다.

(2) 정책일관성(Policy Coherence for Development, PCD)의 확보 : 개발부문에서 RBA를 성공적으로 시행한다 해도, 다른 분야와의 일관성이 확보되지 못한다면 전체적인 인권향상은 
요원해질 것이다. 예를 들어 우리정부가 $\mathrm{ODA}$ 를 통해 특정 국가의 아동 복지사업을 진행하고 있는데, 한국의 기업이 동 국가에 공장을 짓고 아동노동을 착취하는 등 인권유린을 자행한다 면, 결과적으로 해당 수원국의 인권 수준은 향상되기 어려울 것이다. 따라서 개발원조 외의 분 야에서도 동시에 인권에 기반한 업무가 수행될 수 있도록 법적으로 규제하고 이를 관리 감독 할 기구도 필요할 것이다.

\section{다. 인권 인지 제고}

상기 언급한 정치적·법적 조치가 성공적으로 시행되기 위해서는, 북유럽 국가의 성공사례에 서도 알 수 있듯이 인권에 대한 범국민적인 인지가 제고되어야 한다. 우선 국내의 인권 보호에 대한 문화가 정착되어야 국외의 인권문제에 대해 인지할 수 있을 것이다. 오피니언 리더들의 담론 형성과 비젼 제시가 필요한 대목이다.

\section{라. 수원국과의 협력관계 재검토}

공여국의 인권 인식제고에 정부의 의지가 가장 중요하듯, 개도국의 인권문제 해결 또한 해 당 정부의 의지가 가장 중요하다. 때문에 한국 $\mathrm{ODA}$ 의 성공여부는 협력국과의 정치외교적인 관계가 큰 변수가 될 수 있다. 앞서 선진공여국의 사례에서 살펴보았듯이, 권위주의적 정권하 에 인권탄압이 발생하고 있는 수원국이 우리나라의 주요 경제협력국(무역파트너국)일 경우, 우리정부는 어떠한 입장을 취할 것인지에 대한 검토와 성찰이 필요할 것이다.

\section{2. $\mathrm{KOICA}^{28)}$ 차원에서의 조치 방안}

\section{가. RBA 규정의 신설}

$\mathrm{KOICA}$ 설립의 기본근거가 되는 ‘한국국제협력단법’이나 내규인 '한국국제협력단사업시행지 침' 어디에도 개도국의 인권에 관한 언급은 없다. 다만 긴급구호사업 등 인도적지원관련 사업 의 특성상 RBA적인 시각이 반영되었다고 말할 수는 있을 것이다. 하지만 이로써 KOICA 개발 협력사업이 RBA를 기반으로 한다고는 할 수 없으며, RBA가 KOICA의 다양한 개발협력사업 에 반영되도록 하는 규정이 신설되어야 할 것이다.

28) 우리나라의 ODA는 크게 무상원조는 KOICA가, 유상원조는 EDCF가 담당하고 있으나, 앞서 문헌연구에서 다룬 바대로 유상원조는 RBA 도입 관련 사업의 비중이 크지 않기 때문에, 무상원조기관인 $\mathrm{KOICA}$ 의 사례를 중심으로 서술한다. 


\section{나. 관련 예산의 확보}

$\mathrm{RBA}$ 관련예산은 앞서 범정부적 차원에서 언급한 대로 첫째, $\mathrm{RBA}$ 를 목적으로 하는 신규 개 발협력사업의 계획 및 실시를 위한 예산이 있다. 즉 개도국의 거버넌스 향상(사법시스템 구축 등)과 민주주의 수립(참여적개발 등)을 위한 지원, 아동·여성·소수민족·장애인 등 소외계층을 타깃으로 하는 원조사업 등을 위한 예산을 일컫는다.

둘째, KOICA 직원의 역량강화를 위한 예산을 들 수 있다. 이는 개발협력 수행 주체인 $\mathrm{KOICA}$ 직원들이 원조사업을 사전조사, 계획, 수립 및 평가를 할 때 RBA적 시각으로 임할 수 있도록 교육하는 것을 의미한다. 이를 위해 교육 커리큘럼 및 사업 지침서 개발과 교사양성 또 한 연계되어 진행되어야 할 것이다.

\section{다. 인권전문관 제도의 도입}

$\mathrm{KOICA}$ 는 현재 주요 개발 섹터 중 보건의료·교육·건축·젠더 분야의 전문관 제도를 운영하고 있다. 특히 젠더 전문관은 양성평등적적 시각에서 $\mathrm{KOICA}$ 사업의 계획부터 종료까지 전 과정 을 검토 및 조언을 하는 역할을 수행하고 있다. 이와 같이 RBA적 원조사업 수행을 위해 '인권 전문관' 제도를 도입할 필요가 있을 것이다.

\section{라. 모니터링 및 평가(Monitoring \& Evaluation, M\&E)}

현재 $\mathrm{KOICA}$ 에서 실시하는 평가업무는 프로젝트의 사전, 중간, 최종 단계에 걸쳐 진행사항 을 모니터링 및 평가하고 있다. 이는 사업의 투입 대비 결과물에 대한 성공여부와 그 요인을 분석하는 것을 목적으로 하고 있는데, 수혜자 분석 시 $\mathrm{RBA}$ 의 관점이 $\mathrm{M} \& \mathrm{E}$ 심사항목에 반영될 수 있도록 하는 조치가 필요하다.

\section{마. 국별협력전략(Country Partnership Strategy, CPS) 수립 시 반영}

$\mathrm{CPS}$ 는 공여국이 특정 개도국에 대한 원조 계획을 세운 기본 전략서이다. 공여국마다 특기로 하는, 혹은 중요시하는 원조분야가 다르고, 또한 개도국마다 필요로 하는 원조의 우선순위가 다르기 때문에 대부분의 공여국은 수원국에 대한 CPS를 수립하고 있다. 따라서 인권 유린 문제 가 심각한 개도국의 경우 $\mathrm{CPS}$ 수립 시 $\mathrm{RBA}$ 를 최우선 과제로 내세워 반영하도록 해야 한다. 


\section{바. 청렴 및 반부패 장치의 설치}

$\mathrm{KOICA}$ 는 현재 내부 및 외부 감사 수감 시스템을 갖추고 있다. 그러나 ODA사업을 추진하는 과정에 있어 인권유린의 경우를 방지하기 위해 $\mathrm{KOICA}$ 는 RBA에 입각한 청렴 및 반부패 장치 를 추가로 설치 할 필요가 있다.

\section{III. 결론}

1986년의 개발권 선언은 ‘능동적이고 자유로우며 의미 있는 참여’에 대한 권리와, 모든 인권 의 불가분성 및 상호의존성에 대해 명시한 성명서로서, 오늘날의 개발원조 정책과 밀접한 관 계가 있다. 이로써 국제사회는 공여국의 책임성, 개도국과의 상호호혜적 관계, 그리고 원조정 책과 다른 정책간의 일관성을 보다 강력히 요구할 근거를 마련하게 되었다(Piron, 2005). 특 히 1997년 Kofi Annan 전 UN사무총장의 지시로 인권에 기반한 원조(RBA)가 본격적으로 도 입되기 시작했는데, $\mathrm{RBA}$ 를 통해 소외계층에 대한 개발원조를 보다 집중을 할 수 있으며, 나아 가 단순한 수치상의 성장이 아닌 인간 개개인의 존엄성까지 개발의 범주에 넣는 계기가 되었 다고 할 수 있다.

이처럼 공여국이 개도국의 인권문제해결에 의무를 가지는 이유는 인권은 모든 인류에게 주 어진 기본권이며 이는 나 자신뿐만 아니라 타인의 권리를 지킬 의무가 있고, 나아가 인권은 전 인류적 개념으로서 한 국가의 자주권을 상위하기 때문에, 공여국은 개발원조를 통해 개도국의 인권을 수호할 '불완전 의무’를 가지는 것이다.

그러나 세계화에 의해 국경과 국적이 모호해 짐에 따라 다국적기업 등의 인권침해 등 국가 권력의 사각지대에 놓인 인구가 증가하고 있다. 때문에 UN을 중심으로 한 범국가적이고 강력 한 규제조치 및 인권보호 방안이 마련되어야 한다. 국제금융기구는 거버넌스와 법치주의, 빈 곤퇴치전략과 참여적 개발을 중심으로 $\mathrm{RBA}$ 사업을 수행하고 있다. 대표적인 북유럽 공여기관 인 영국의 $\mathrm{DfID}$ 는 빈곤층의 '참여적 접근을 통한 권한강화'를, 스웨덴의 Sida는 '빈곤층 삶의 향상 및 민주적 개발'을 원조의 기본 목표로 설정, 모범적인 $\mathrm{RBA}$ 를 시행하고 있다. 또한 최근 그 역할의 중요성이 강조되고 있는 국제 $\mathrm{NGO}$ 는 국가 및 국제 개발원조 기관들로 하여금 인권 수호의 의무를 다하도록 압력을 가하는 수단으로서의 역할을 수행하고 있다. 
이러한 세계적 추세와는 반대로, 우리나라 ODA의 인권적 시각은 아직 걸음마 단계라고 할 수 있다. 한국은 인권관련 국제조약을 대부분 비준하고 있으며, 이는 국내법에도 반영되어 관 련 법률이 제정, 시행되고 있다. 국내의 인권적 인식 수준은 높은 편이며 따라서 ODA에 RBA 를 적용할 기본적인 환경은 갖추고 있다고 판단된다. 그러나 '인권’에 대한 담론을 과거 한국 의 개발시대의 '저항적 운동' 개념으로 보는 시각들이 다소 남아있고, 여러 가지 국익과 관련 한 전략적 판단으로 인해 실제 $\mathrm{RBA}$ 적용은 수월하지 못할 가능성이 있다고 판단된다.

하지만 국제 경제와 문화 부분에서 한국의 영향력이 강해짐에 따라, 국제사회는 한국이 책 임 있는 일원으로서의 역할을 할 것을 요구하고 있다. 특히 한국이 2011년 OECD DAC에 가입 함에 따라, 개발협력분야에서의 국제사회와의 약속과 공여국으로서의 책임을 지킬 의무가 강 조되고 있다. 때문에 이제는 한국이 국제적인 인권과 개발 관련 담론의 흐름을 인식하고, 그에 따른 $\mathrm{RBA}$ 도입에 대한 진지한 검토를 할 시기가 되었다고 할 수 있겠다. 


\section{참고문헌}

\section{1. 국내문헌}

오은정 (2012) KOICA 성평등 개발협력 사업 수행방안 연구. 한국국제협력단: 성남.

한국국제협력단 (2011) 모자보건 ODA 프로그램 모델 연구. 한국국제협력단: 성남.

전광석 (2010) 한국헌법론. 법문사: 서울

정정길 (2010) 정책학원론. 대명출판사: 서울

\section{2. 국외문헌}

Alston P. \& Robinson M. (2005) The Challenges of Ensuring the Mutuality of Human Rights and Development Endeavours. in Alston P. \& Robinson M. (eds) Human Rights and Development: Towards Mutual Reinforcement. Oxford University Press: Oxford.

Arzabe P. (2001) Human Rights: A New Paradigm. in Genugten W. \& Perez-Bustillo C. (eds) The Poverty of Rights: Human Rights and the Eradication of Poverty. CROP: New York.

Bachrach P. \& Baratz M. (1962) Two Faces of Power. American Political Science Review 56.

Barratt B. (2008) Human Rights and Foreign Aid. Routledge: Oxon.

Betcherman G., Fares J., Luinstra A. \& Prouty R. (2005) Child Labor, Education, and Children's Rights in Alston P. \& Robinson M. (eds) Human Rights and Development: Towards Mutual Reinforcement. Oxford University Press: Oxford.

Beuchelt T. \& Virchow D. (2012) Food sovereignty or the human right to adequate food: which concept serves better as international development policy for global hunger and poverty reduction? Agric Hum Vaules 29, 259-273.

Cornwall A. \& Nyamu-Musembi C. (2004) Putting the 'rights-based approach' to development into perspective. Third World Quarterly 25 (8), 1415-1437.

Cousins B. (2009) Capitalism obscured: the limits of law and rights-based approaches to poverty reduction and development. The Journal of Peasant Studies 36 (4), 893-908. 
Dañino R. (2005) The Legal Aspects of the World Bank's Work on Human Rights: Some Preliminary Thoughts. in Alston P. \& Robinson M. (eds) Human Rights and Development: Towards Mutual Reinforcement. Oxford University Press: Oxford.

Drèze J. (2005) Democracy and the Right to Food. in Alston P. \& Robinson M. (eds) Human Rights and Development: Towards Mutual Reinforcement. Oxford University Press: Oxford.

Duncan R. (1972) Characteristics of Perceived Environmental Uncertainty. Administrative Science Quarterly 17, 313-327.

Eberl J., Kinney E. \& Williams M. (2011) Foundation for a Natural Right to Health Care. Journal of Medicine and Philosophy 36, 537-557.

Fukuda-Parr S. (2006) Millennium Development Goal 8: Indicators for International Human Rights Obligations? Human Rights Quarterly 28, 966-997.

Gaiha R. (2003) Does the Right to Food Matter? Economic and Political Weekly, 4269-4276.

Gauri V. \& Gloppen S. (2012) Human Rights-Based Approaches to Development: Concepts, Evidence and Policy. Polity 44 (4), 485-503.

Ghai Y. (2001) Human Rights and Social Development: Toward Democratization and Social Justice. Democracy, Governance and Human Rights Programme Paper No.5. UNRISD.

Hafner-Burton E. \& Tsutsui K. (2005) Human Rights in a Globalizing World: The Paradox of Empty Promises. American Journal of Sociology 110 (5), 1373-1411.

Haugen H. (2012) International Obligations and the Right to Food: Clarifying the Potentials and Limitations in Applying a Human Rights Approach When Facing Biofuels Expansion. Journal of Human Rights 11 (3), 405-429.

Hoen E. (2003) TRIPS, Pharmaceutical Patents and Access to Essential Medicines: Seattle, Doha and Beyond. at http://cdrwww. who.int/intellectualproperty/topics/ip/tHoen.pdf [accessed 2013.1.13]

Horta K. (2002) Rhetoric and Reality: Human Rights and the World Bank. Harvard Human Rights Journal 15, 227-243.

Howard-Hassmann R. (2011) Universal Women's Rights Since 1970: The Centrality of Autonomy and Agency. Journal of Human Rights 10, 433-449.

ILO (2002) Every Child Counts: New Global Estimates on Child Labour. International Programme on the Elimination of Child Labour (IPEC) \& Statistical Information and Monitoring Programme on Child Labour (SIMPOC): Geneva. 
Leeuwen F. (2009) Women's Rights Are Human Rights: The Practice of the United Nations Human Rights Committee and the Committee on Economic, Social and Cultural Rights. Intersentia: Oxford.

Meier B. (2010) Global Health Governance and the Contentious Politics of Human Rights: Maintreaming the Right to Health for Public Health Advancement. HeinOnline at http://heinonline. org.

Narula S. (2005) The Right to Food: Holding Global Actors Accountable Under International Law. HeinOnline at http://heinonline.org.

Nelson P. \& Dorsey E. (2003) At the Nexus of Human Rights and Development: New Methods and Strategies of Global NGOs. World Development 31 (12), 2013-2026.

Piron L. (2005) Rights-based Approaches and Bilateral Aid Agencies: More Than a Metaphor? IDS Bulletin 36 (1), 19-30.

Plant M. (2005) Human Rights, Poverty Reduction Strategies, and the Role of the International Monetary Fund. in Alston P. \& Robinson M. (eds) Human Rights and Development: Towards Mutual Reinforcement. Oxford University Press: Oxford.

Ramdas K. \& Janus K. (2011) Ratifying Women's Rights. Policy Review 169, 29-38.

Rathgeber E. (1990) WID, WAD, GAD: Trends in Research and Practice. The Journal of Developing Areas 24 (4), 489-502.

Ripley B. \& Franklin G. (1986) Policy Implementation and Bureaucracy. Dorsey: Chicago.

Roberts B. (1996) The Beijing Fourth World Conference on Women. The Canadian Journal of Sociology 21 (2), 237-244.

Robinson M. (2005) What Rights Can Add to Good Development Practice. in Alston P. \& Robinson M. (eds) Human Rights and Development: Towards Mutual Reinforcement. Oxford University Press: Oxford.

Romero-Ortuño R. (2004) Access to health care for illegal immigrants in the EU: should we be concerned? European Journal of Health Law 11, 245-272.

Sen A. (2009) The Idea of Justice. Harvard University Press: Cambridge, MA. 
UN Women. (2010) About UN Women, at http://www. unwomen. org/about-us/about-un-women/ [accessed 2013.1.15]

UNICEF (2008) Child labour and school attendance: Evidence from MICS and DHS surveys. Seminar on child labour, education and youth employment. at http://www.childinfo.org/

Uvin P. (2004) Human Rights and Development. Kumarian Press: Bloomfield. 